\title{
DEFENSES TO SECTIONS 2(c), 2(d), AND 2(e) OF THE ROBINSON-PATMAN ACT.
}

\begin{abstract}
A recent Supreme Court interpretation of the Robinson-Patman Act which, for the first time, required a seller to extend proportionally equal promotional aid to buyers at different functional levels, illustrates the uncertain nature of the scope, and, concomitantly, the defenses to sections $2(c), 2(d)$ and $2(e)$ of the Act. This note attempts to explicate the defenses that have been successfully used to rebut charges under these sections. Special emphasis is placed upon clearly delineating the elements of court and FTC favored defenses on both the merits and jurisdictional grounds to charges of section $2(c), 2(d)$ and $2(e)$ violations.
\end{abstract}

A Federal Trade Commission study conducted in the early 1930's revealed that large volume buyers frequently utilize their immense purchasing power to disadvantage smaller competitors by obtaining unearned concessions from their common supplier.' In order to eliminate such indirect price reductions, ${ }^{2}$ Congress enacted sections 2(c), (d), and (e) in the Robinson-Patman Amendments to the

' FTC, Final Report on the Chain Store INvestigation, S. Doc. No. 4, 74th Cong., ist Sess. (1935). The study is replete with examples of buyers demanding payments for illusory brokerage services, discounts, allowances and outright price reductions. Id. at 25,63 . The Commission found that $15 \%$ of the selling price differential between chain stores and non-chain stores was attributable to the former's powerful bargaining position. Id. at 55 . However, the findings of this report have been criticized as failing to accurately estimate the lower operating costs of chains. See Adelman, Price Discrimination as Treated in the Attorney General's Report, 104 U. PA. L. Rev. 222, 232 (1955).

${ }^{2}$ Attempts by the FTC to use the original Clayton Act $\S 2$, ch. 323, 38 Stat. 730 (1914), to restrain price reductions induced by buyers failed because the courts narrowly interpreted the purpose of the Act as the protection of competition only between the seller and his competitors. See, e.g., National Biscuit Co. v. FTC, 299 F. 773 (2d Cir.), cert. denied, 266 U.S. 613 (1924); Mennen Co. v. FTC, 288 F. 774 (2d Cir.), cert. denied, 262 U.S. 759 (1923). For a general discussion of the background of the Robinson-Patman Amendments sce W. PATMAN, COMPLETE Guide to the Robinson-Patman Act 1-11 (1963) [hereinafter cited as Patman]; F. Rowe, Price Discrimination Under The Robinson-Patman Act ch. 1, $3-23$ (1962, Supp. 1964) [hereinafter cited as RowE]. 
Clayton Act. ${ }^{3}$ Section 2(c) ${ }^{4}$ outlaws indirect price reductions accomplished through the payment of "dummy" brokerages. ${ }^{5}$ Thus, the payment or receipt of a direct commission, brokerage, or other compensation as well as "discounts in lieu thereof" are prohibited unless earned by the actual performance of distributive services. ${ }^{6}$ To

${ }^{3}$ Robinson-Patman Act $\S 2,15$ U.S.C. § 13 (1964), formerly 38 Stat. 730 (1914). See generally Comment, The Robinson-Patman Act in Action, 46 YALE L. Rev. 447 (1937).

415 U.S.C. $\$ 13$ (c) provides: "It shall be unlawful for any person engaged in commerce . . . to pay or grant, or to receive or accept, anything of value as a commission, brokerage, or other compensation, or any allowances or discount in liey thereof, except for services rendered in connection with the sale or purchase of goods, wares or merchandise, either to the other party to such transactions or to an agent, representative, or other intermediary therein where such intermediary is acting in fact for or in behalf, or is subject to the direct or indirect control, of any party to such transactions other than the person by whom such compensation is so granted or paid." See generally Miehael, Brokerage and the Robinson-Patman Act, 10 LoYoLA L. Rev. 165 (1961); Oppenheim, Administration of the Brokerage Provision of the Robinson-Patman Act, 8 GEO. WASH. L. Rev. 511, 516-520 (1940); Comment, Some Aspects of Interpretation and Application of the Brokerage Clause of the Robinson-Patman Act, 10 DePaUL. L. Rev. 65 (1960) [hereinafter cited as Comment, 10 DePaul L. Rev.]; Note, 41 Notre Dame Law. 355 (1966).

"The practice of large buyers in demanding that the seller pay "brokerage" to "dummy" brokers who were employed by the buyers and rendered no services to the seller was apparently the primary target of the Act. FTC v. Henry Broch \& Co., 363 U.S. 166, 169 (1960). See also S. REP. No. 1502, 74th Cong., 2d Sess. (1936); H.R. REP. No. 2287, 74th Cong., 2d Sess. 14-15 (1936); note 6 infra. The recognition of this narrow purpose of the brokerage clause has been significant in recent determinations that a "services rendered" defense should be available to any defendant charged under the Act. See Empirc Rayon Yarn Co. v. American Viscose Corp., 364 F.2d 491 (1966), rev'g 354 F.2d 182 (2d Cir. 1965), cert. denied, 385 U.S. 1002 (1967); Hruby Distrib. Co., 61 F.T.C. 1429, 1447 (1962); Flotill Prods. Co., [1963-1965 Transfer Binder] TRADE REG. REP. I 16970, at 22,047 (FTC 1964); notes 35-38 infra and accompanying text.

' The Congressional report on the bill ultimately enacting $\$ 2$ (c) emphasizes that the provision “. . . permits payments of a compensation by a buyer to his broker or an agent for services aetually rendered in his behalf; likewise, by a buyer to his broker or agent for services in connection with the purchase of goods actually rendered in his behalf; but it prohibits the direct or indirect payment except for such services rendered." H.R. ReP. No. 2287, 74th Cong., 2d Sess. 15 (1936). The section's singular interest in dummy brokerage was further underscored by Senator Logan, Chairman of the Subcommittec of the Senate Judiciary Committec: "The bill does not affect legitimate brokerage either directly or indirectly. Wherc the broker renders service to the buycr or to the seller the bill does not prohibit the payment of brokerage. It is not aimed at legitimate brokerage, because brokerage is necessary. . . . However, it was found that whilc direct price discrimination could not be indulged in, the buyer, if he were sufficiently powerful, could designate someone and say, 'that is my broker' . . . . The buyer would say to the seller, you must sell through that man, and you must pay him a certain percentage or amount of brokerage'; and when the so-called broker or dummy broker received what was paid, he turned it over to the buyer, and in that way a price discrimination was brought about." 80 CONG. ReC. 6281 (1936).

Representative Celler foresaw possible misinterpretations of the scope of $\S 2(\mathrm{c})$. "The conference report, in its reference to brokerage allowances, fails to takc due notice of the fact that we put into the final bill the words 'except for services rendered.' That means if actual 
combat the practice of giving lower prices through selective payments for promotional services or facilities, ${ }^{7}$ section 2 (d) requires that such payments be available on proportionally equal terms to all customers. ${ }^{8}$ This "proportionally equal" criteria also determines a

brokerage service is rendered it must be allowed to be paid for; it must be either reflected in price or discount and allowance. Many respectable and honorable business houses have brokerage departments or have organized separate entities which they may own in whole or in part and which perform legitimate brokerage functions; which departments or entities expend money in research, investigation, experimentation, advertising. They actually render valuable brokerage service. Yet if they be directly or indirectly connected with the seller or buyer, no brokerage allowance can be made, although in the language of the words we inserted services were actually rendered. I know that evcrybody watching the bill and interested in making it sound has assumed tbat the insertion of the words 'for services rendered' meant that payment could be made whenever services were actually rendered." 80 CONG. REC. 9420 (1936) (emphasis added).

Representative Celler's concern was subsequently proven justified as $\S 2(c)$ became one 'of the most active producers of litigation under the Act. See Note, 41 Notre Dame Law. 355, 356 (1966). See generally C. Austin, Price Discrimination and Related Problems Under THE RoBinson-PATMAN ACt (3d ed. 1959) [hereinafter cited as Austin]; Michael, supra note 4.

Because of the early decisions negating the services rendered exception, see note 21 infra and accompanying text, the precise nature of the services that would warrant legitimate brokerage payment have never been described. Early attempts by defendants to defend against section 2(c) violations, which were unsuccessful because of the buyer-seller relationship of the parties, indicate that such services as the broker's selection of a seller for a buyer, information concerning present market prices and conditions, examination and testing of commodities, and descriptions of goods may be the type of services that will constitute "services rendered." See Oliver Bros., Inc. v. FTC, 102 F.2d 763, 766 (4th Cir. 1939); Biddle Purchasing Co. v. FTC, 96 F.2d 687, 693 (2d Cir.), cert. denied, 305 U.S. 634 (1938). More recently, proof of similar services rendered has successfully relieved a defendant of liability for a seller-buyer brokerage. See notes 34-37 infra and accompanying text.

7 "Still another favored medium for the granting of oppressive discrimination is found in the practice of large buyer customers to demand, and of their sellers to grant, special allowances in purported payment of advertising and other sales-promotional services, which the customer agrces to render with refercnce to the seller's product or sometimes with reference to his business generally. Such an allowance becomes unjust when the servicc is not rendcred, the payment is grossly in excess of its value, or when in any case the customer is deriving from it benefit to his own business and is thus enabled to shift to his vendor substantial portions of his own advertising cost, while his smaller competitor, unable to command such allowance, cannot do so." H.R. ReP. No. 2287, 74th Cong., 2d Sess. 15-16 (1936); S. ReP. No. 1502, 74th Cong., 2d Sess. 7 (1936).

'15 U.S.C. § 13(d) provides: "It shall be unlawful for any person engaged in commerce to pay or contract for the payment of anything of value to or for the benefit of a customer of such person in the course of such commerce as compensation or in consideration for any services or facilities furnished by or through sueh customer in connection with the processing, handling, sale or offering for sale of any products or commodities manufactured, sold, or offered for sale by such persons, unless such payment or consideration is available on proportionally equal terms to all other customers competing in the distribution of such products or commodities." See generally Comment, Recent Problems Under Section 2(d) of the Robinson-Patman Act, $29 \mathrm{U}$. CHI. L. Rev. 160 (1961) [hereinafter cited as Comment, 29 U. CHI. L. Rev.]. As explained by 
seller's obligation to his buyers under section 2(e) if the seller himself furnishes the promotional services or facilities. ${ }^{9}$ Although certain defenses were specifically made available to the contemporancously enacted prohibition upon direct price discrimination embodied in section 2(a) of the Robinson-Patman Act, ${ }^{10}$ the proscriptions upon the indirect methods of discrimination were phrased in more unqualified terms. However, the imprecision of the language of sections 2(c), (d), and $(e)^{\prime \prime}$ has left the exact scope of their prohibitions against indirect

Representative Utterback, chairman of the Senate-House conferees: "The existing evil at which this part of the bill is aimed is, of course, the grant of discriminations under the guise of payments for advertising and promotional services, which, whether or not the services are actually rendered as agreed, result in an advantage to the customers so favored as compared with others who have to bear the cost of such services themselves." 80 CoNG. REC. 9418 (1936).

${ }^{9} 15$ U.S.C. $\$ 13($ e) provides: "It shall be unlawful for any person to discriminate in favor of one purchaser against another purchaser or purchasers of a commodity bought for resale with or without processing, . . . by contributing to the furnishing of, any services or facilities connected with the processing, handling, sale, or offering for sale of such commodity so purchased upon terms not accorded to all purchasers on proportionally equal terms." For a discussion of sections 2(d) and 2(e), see PATMAN, ch. 4; Rowe, ch. 13; Kintner, Merchandising Allowances and Services: Sections 2(d) and 2(e) of the Robinson-Patman Act, 41 Notre DAME LAW. 364 (1966).

${ }^{10}$ is U.S.C. \& 13(a) provides in pertinent part: “[1]t shall be unlawful for any person engaged in commerce, ... e either directly or indirectly, to discriminate in price between different purchasers of commodities of like grade and quality, . . . . where the effect of such discrimination may be substantially to lessen competition or tend to create a monopoly in any line of commerce, or to injure, destroy, or prevent competition with any person who either grants or knowingly receives the benefit of such discrimination, or with customers of either of them: Provided, That nothing herein contained shall prevent differentials which make only due allowance for differences in the cost of manufacture, sale, or delivery resulting from the differing methods or quantities in which such commodities are to such purchasers sold or delivered: . . . And provided further, That nothing herein contained shall prevent price changes from time to time where in response to changing conditions affecting the market for or the marketability of the goods concerned, such as but not limited to actual or imminent deterioration of perishable goods, obsolescence of seasonal goods, distress sales under court process, or sales in good faith in discontinuance of business in the goods concerned." See generally PatMAN at 11-101; Rowe at 87-204; Blaekford, A Survey of Section 2(a) of the Robinson-Patman Act, 41 NotRE Dame Law. 285 (1966); Note, 41 Notre Dame Law. 317 (1966). The proscriptions of section 2(a) are limited by section 2(b): "Upon proof being made, at any hearing on a complaint under this section, that there has been discrimination in price or services or facilities furnished, the burden of rebutting the prima facie case thus made by showing justification shall be upon the person charged with a violation of this section, and unless justification shall be affirmatively shown, the Commission is authorized to issue an order terminating the discrimination: Provided, however, That nothing herein contained shall prevent a seller rebutting the prima facie case thus made by showing that his lower price or the furnishing of services or facilities to any purchaser or purchasers was made in good faith to mect an equally low price of a competitor, or the services or facilities furnished by a competitor." See generally Maycr, Affirmative Defense to Prima Facie Violations of the Robinson-Patman Act, 41 NotRE DAME LAW. 310 (1966). See notes $173-90$ infra and accompanying text.

"Mr. Justice Frankfurter has noted that "precision of expression is not an outstanding 
discrimination unsettled. Consequently, the nature and validity of defenses to these sections remain unclear.

\section{Section 2(c)-The Brokerage Clause}

The Federal Trade Commission and the courts initially took the position that the statutory defenses against section 2(a) charges of direct price discrimination-cost justification, ${ }^{12}$ good faith meeting of competition, ${ }^{13}$ and lack of competitive injury ${ }^{14}$ to or discrimination among buyers ${ }^{15}$-were unavailable to a party charged with a brokerage clause violation. ${ }^{16}$ This more rigid treatment of an alleged violator of section 2(c) cannot be justified on the basis that the consequences of a brokerage clause violation are more reprehensible than those stemming from a violation of section 2(a) since the ultimate economic effect of a violation of either section, a reduction of the buyer's cost, is equivalent. ${ }^{17}$ Rather, the restriction of effective defenses to section 2(c) was intended to promote regulatory efficiency by forcing the parties to confine their predatory practices to overt price differentials encompassed within section 2(a) on the theory that such direct discriminations were more readily detectable. ${ }^{18}$

characteristic of the Robinson-Patman Act. . . ." Automatic Canteen Co.v. FTC, 346 U.S. 61, 65 (I953). This statement has been described as a "generous . . . understatement" by those who consider "section 2(c) . . . a prime example of nonintelligible draftsmanship." See Note, 41

Notre Dame Law. 355 (1966).

12 See notes 60-75 infra and accompanying text.

${ }^{13}$ See notes $173-90$ infra and accompanying text.

14 See notes $169-72$ infra and accompanying text.

is See notes 27-32 infra and accompanying text.

16 "It is perfectly clear that all three of these practices [described in 2(c), (d) and (e)] were forbidden because of their tendency to lessen competition and create monopoly, without regard to their effect in a particular case; and there is no reason to read into the seetions forbidding them the limitations contained in section 2(a) having relation to price discrimination . . .." Great Atl. \& Pac. Tea Co.v. FTC, 106 F.2d 667 (3d Cir. 1939), cert. denied, 308 U.S. 625 (1940), citing Oliver Bros. v. FTC, 102 F.2d 763, 766-68 (4th Cir. 1939) (dicta); accord, Southgate Brokerage Co.v. FTC, I50 F.2d 607, 610 (4th Cir.) (dicta concerning competitive injury), cert. denied, 326 U.S. 774 (1945); Webb-Crawford Co. v. FTC, I09 F.2d 268 (5th Cir.), cert. denied, 310 U.S. 638 (1940); Biddle Purchasing Co. v. FTC, 96 F.2d 687 (2d Cir.), cert. denied, 305 U.S. 634 (1938); see Oppenheim, supra note 4, at 520-26.

${ }^{17}$ Obviously, the effective cost of the purchased product is reduced equally by an initial cut in price or by a rebate of the price paid in the form of brokerage for illusory services. Thus, the activities proscribed by $\S 2$ (c) differ only from the price discriminations of $\S 2(a)$ in the methods used to obtain the effect. See Report of the Attorney General's National Committee to Study ANTItrust Laws, 19I-92 (I955) [hereinafter cited as ATt'Y Gen. ReP.]; $c$. Note, 48 VA. L. REv. 574, 595 (1962). But see notes 170-72 infra and accompanying text.

is "[O]ne of the principal evils inherent in the payment of brokerage fees by the seller to the 
The proscriptions of section 2(c) as originally promulgated apparently were not absolute, for the text of that section excludes compensation paid "for services rendered" from the stigma of illegitimate brokerages. ${ }^{19}$ Nevertheless, early judicial decisions emasculated this "services rendered" exception, ${ }^{20}$ ruling that the buyer or his agent could not, as a matter of law, perform the services contemplated by the provision. ${ }^{21}$ The rationale for this ban upon sellerbuyer brokerage payments was that the conflicting interests of the buyer and seller in a sales transaction would make it impossible for either party to faithfully and effectively serve the other's interest. ${ }^{22}$ Consequently, the courts reasoned that Congress necessarily intended

buyer directly or through an intermediary, is the fact that this practice makes it possible for the seller to discriminate in price without secming to do so. If a price discount is given as a brokerage payment to a controlled intermediary, it may be and often is concealed from other customers of the seller. One of the main objectives of section 2(c) was to force pricc discrimination out into the open where they would be subject to the scrutiny of those interested . . . Biddle Purchasing Co. v. FTC, 96 F. 2d 687, 692 (2d Cir.), cert. denied, 305 U.S. 634 (1938); see Southgate Brokerage Co. v. FTC, 150 F.2d 607, 609, 610 (4th Cir.), cert. denied, 326 U.S. 774 (1945); Elman, The Robinson-Patman Act and Antitrust Policy: A Time for Reappraisal, 42 WASH. L. REV. 1, 23 (1966).

${ }^{19}$ See I5 U.S.C. \$13(c) (1964) (supra note 4); H.R. REP. No. 287, 74th Cong., 2d Sess. 15 (1936), comments of Senator Logan, 80 CoNG. REC. 6281 (1936), and comments of Representative Celler, 80 CoNG. REC. 9420 (1936) (supra note 6).

${ }^{20}$ See generally Bison, The "Services Rendered" Provision in the Brokcrage Section of the Robinson-Patman Act, 4 I Notre Dame Law. 326 (1966).

${ }^{2}$ See Bison, supra note 20 , at 327. The "services rendered" wording was confined by the Fifth Circuit to the preceding "allowance or discount" terminology, causing all brokerage payments to purchasing parties to be considered per se illegal. Webb-Crawford Co. v. FTC, 109 F.2d 268 (5th Cir. 1940). Further, the Third Circuit ruled that 2(c) was an absolute prohibition of priee reductions or brokerage payments between the parties or their agents, thus outlawing all seller-buyer brokerage compensation in any form. Great Atl. \& Pac. Tea Co. v. FTC, 106 F. 2d 667, 673, 674-75 (3d Cir. 1939), cert. denied, 308 U.S. 625 (1940); see c.g., Oliver Bros., Inc. v. FTC, I02 F.2d 763 (4th Cir. 1939); Biddle Purchasing Co. v. FTC, 96 F.2d 687 (2d. Cir.), cert. denied, 305 U.S. 634 (I938).

The effect of this restriction of the "services rendered" defense in addition to the refusal to accord defenses available under $\S 2$ (a) to $\S 2$ (c), see note I6 supra and accompanying text, gave the brokerage clause a per se proscriptive quality. See Note, 41 Notre Dame LAw. 355, 356-57 (1966). This result received intense criticism by commentators on the ground that it discouraged competition, an effect contrary to the intent of the antitrust laws in general and, in fact, gave independent brokers a monopoly. See, e.g., Rowe 539-55; Elman, supra note 18, at 2325; Oppenheim, Federal Antitrust Legislation: Guideposts to a Revised National Antitrust Policy, 50 Mich. L. Rev. I 139, $1205-07$ n.178 (1952); notes 24, 54, 57 infra and accompanying text.

${ }^{22}$ For example, the Third Circuit concluded: "Conflicting interests are always engaged when an attempt is made by buyers and sellers to arrive at a market price for commodities. We entertain no doubt that it was the intention of Congress to prevent dual representation by agcnts 
the proscription of section 2(c) to be absolute, concluding that the allowance of brokerage payments between a buyer and seller would lead to such "fraud and oppression" as to destroy the effectiveness of the amendment in curtailing indirect price discrimination. ${ }^{23}$ As a result of these decisions, only independent brokers could lawfully receive brokerage, as they alone served only one party's interest. ${ }^{24}$ Despite this detrimental effect, the absolute interpretation of section 2 (c) rcceived universal acceptance ${ }^{25}$ until the Supreme Court's

purporting to deal on behalf of both buyer and seller . . . [Thus,] [t] he agent cannot serve two masters . . ." Great Atl. \& Pac. Tea Co. v. FTC, 106 F.2d 667, 674 (3d Cir. 1939), cert. denied, 308 U.S. 625 (1940). See generally Elman, note 18 supra, at 23; 51 HARV. L. REV. 1303 (1939); 7 U. CHI. L. Rev. 189 (1939); 47 YALE L.J. 1207 (1939). More recently, the First Circuit has echoed this distrust of such seller-buyer cooperation: "[W]e would be naive if we believed that buyers would have any great solicitude for the welfare of their commercial antagonists, sellers. The seller wants the highest price he can get and the buyer wants to buy as cheaply as he can, and to achieve their antagonistic ends neither expects the other, or can be expected, to lay all his cards face up on the table." Forster Mfg. Co. v. FTC, 335 F.2d 47, $55-56$ (lst Cir. 1964). See Bison, supra note 20, at 327-30.

${ }^{23}$ The argument that a seller's payment of brokerage could be justified when made for services rendered was rejected on the ground that "[t]he construction contended for makes much of its [brokerage clause] language meaningless; it does violence to the purpose of the Act and has been explicitly rejected in other circuits. It is plain enough that the paragraph [section 2(c)], taken as a whole, is framed to prohibit the payment of brokerage in any guise by one party to the other, or the other's agent ...." Quality Bakers of America v. FTC, 114 F.2d 393, 398 (lst Cir. 1940); Great Atl. \& Pac. Tea Co. v. FTC, 106 F.2d 667, 674 (3d Cir. 1939), cert. denied, 308 U.S. 625 (1940). See notes 34-58 infra and accompanying text.

${ }^{24}$ The immediate effect was to give the independent broker a virtual monopoly of the brokerage services market. See note 21 supra. In common sales transactions betwecn sellers and small buyers, brokerage services are required to distribute the goods, usually shipped in large quantities, to the individual small buyer. The cost of these services are always upon the buyer, either in cost of the broker he hires or in the seller's price which reflects seller's payments to his own broker. Under the interpretation of 2(c) provided by Great Atl. \& Pac. Tea Co.v. FTC, 106 F.2d 667 (3d Cir. 1939), cert. denied, 308 U.S. 625 (1940), see note 21 supra, the buyers who are too small individually to perform brokerage services for themselves will not be encouraged to form cooperative associations to perform the services because they would be unable to recover from the seller, either through direct payments or through discounts in price, the cost of performing these services. Thus, the independent wholesaler becomes the sole distributor to small buyers, and, as a result, the price which these small buyers must pay to the seller is higher than the cost incurred by a fully integrated company because the former's price reflects the profit element of the independent retailer's charge while the latter's reflects only the cost of distributing. Therefore, contrary to the intent of Congress, the small buyer is placed in a disadvantageous competitive position vis-a-vis the integrated firm because the small buyer's price to the consumer will be higher, reflecting his higher payments for distribution. See ATT'Y GEN. REP at 190; Rowe at 355-56; Elman, note 18 supra, at 23-25.

${ }^{25}$ See, e.g., Southgate Brokerage Co. v. FTC, 150 F.2d 607 (4th Cir.), cert. denied, 326 U.S. 774 (1945) (professional brokers purchasing for their own retail accounts); Modern Mktg. Serv., Inc. v. FTC, 149 F.2d 970 (7th Cir. 1945); Quality Bakers of America v. FTC, 114 F.2d 393 (lst Cir. 1940); Biddle Purchasing Co. v. FTC, 96 F.2d 687 (2d Cir.), cert. denied, 305 U.S. 634 
decision in FTC v. Henry Broch \& $\mathrm{Co}^{26}$

In Broch the Court significantly weakened the "per se thrust"27 of section 2(c) by implying that only unjustified discriminatory payments of brokerage were banned. ${ }^{28}$ An independent broker, employed by a seller, was found to have violated section 2(c) by reducing the commission charged the seller and thereby enabling the latter to lower his price to the one buyer who had refused to deal at the seller's previously quoted price. ${ }^{29}$ However, in dicta, the Court stated

(1938) (payment to market information service of buyers.).

${ }^{26} 363$ U.S. 166 (1960) (5-4 decision). See generally RowE, at 343-46; Rill, Brokerage Under the Robinson-Patman Act: Toward a New Certainty, 41 Notre Dame LAw. 337 (1966); Comment, 10 DePaul L. Rev. at 75-84; Comment, 42 N.C.L. Rev. 457 (1964); Comment, Brokerage and the Broch Case: Conflict and Compromise Between Sections 2(a) and 2(c) of the Robinson-Patman Act, 28 U. CHI. L. REV. 505 (1961) [hereinafter cited as Comment, $28 \mathrm{U}$. ChI. L. ReV.]; 46 lowa L. Rev. 700 (1961); 13 Stan. L. ReV. 133 (1960).

${ }^{27} 363$ U.S. at 189 (dissent). For a discussion of the argument of the dissent of Broch see note 29 infra and aceompanying text.

${ }^{28}$ The limitation of $\S 2$ (c) to discriminatory payments may be inferred from the empbasis in Broch upon that characteristic of illegal brokerage. Mr. Justice Douglas, writing the majority opinion, first decided tbat ". . . the act is aimed at price discrimination . . . "Id. at 174. This statement may be interpreted to mean that 2 (c) is applicable to price reductions or brokerage only if discriminatory; that is, if preference in price is given to favored buyers. See Empire Rayon Yarn Co. v. American Viscose Corp., 364 F.2d 491 (2d Cir. 1966), cert. denied, 385 U.S. 1002 (1967); Hruby Distrib. Co., 61 F.T.C 1437 (1962). Mr. Justice Douglas then stated that the decision in Broch did not mean tbat ". . . every reduction in price, coupled with a reduction in brokerage, automatically compels the conclusion tbat an allowance 'in lieu' of brokerage has been granted. As the Commission itself bas made clear, whetber such a reduction is tantamount to a discriminatory payment of brokerage depends on the circumstances of eacb case." 363 U.S. at 175-76 (emphasis added). The term discrimination, or its concomitants "preference" and "concession," appear ten times in the opinion.

1t bas been contended that this emphasis upon discrimination is wholly correct and consistent with the language of tbe section which may be defined as "a corrollary provision of an antidiscrimination statute." Rill, supra note 26 , at 338 . It is also relevant to note the basic objectives of the Robinson-Patman Act: "The object of the bill . . . is to amend section 2 of the Clayton Act so as to suppress more effectually discriminations betwecn customers of the same seller . . . . Such discriminations are sometimes effected directly in prices, including terms of sale; and sometimes by separate allowances to favored customers for purported services which are unjustly discriminatory in their result against other customers. The Bill is accordingly drawn in six lettered subsections, of which the first four, (a), (b), (c), (d), contain substantive measures directed at the more prevalent forms of discrimination . . ." H.R. REP. No. 2287, 74th Cong., 2d Sess. 7 (1936) (emphasis added). But see Robinson v. Stanley Home Products, Inc., 272 F.2d 601, 604 (1st Cir. 1959); FTC v. Washington Fisb \& Oyster Co., 271 F.2d 39, 44 (9th Cir. 1959); Southgate Brokerage Co. v. FTC, 150 F.2d 607, 609 (4tb Cir.), cert. denied, 326 U.S. 774 (1945). See generally Rill, note 26 supra, at 338-41. Given the Broch cmphasis upon discrimination, it may now be essential to the invocation of section 2(c) to demonstrate that the seller sells to customers other than those to whom illegal brokerage has been allowed and to show the prices charged. See Comment, 28 U. Chi. L. Rev. at 519.

${ }^{29}$ The salient questions before the Court were whether an independent seller's broker was 
that circumstances might exist in which a conjunctive reduction of brokerage and price would not be violative of the brokerage clause. ${ }^{30}$ Further, the Court implied that had the buyer rendered services to the seller or had there been anything in the seller's method of dealing with the buyer that justified the grant of a discriminatory price, these facts may have constituted "circumstances" sufficient to relieve the seller of liability. ${ }^{31}$ Thus, by recognizing unjustified discrimination as the basis of a brokerage clause violation, ${ }^{32}$ the Court implicitly challenged the previous "absolute" interpretation of section 2(c). However, in neglecting to identify the manner in which a seller could avoid illegality, the Court failed to delineate the precise nature of the section's proscriptions. ${ }^{33}$

included as "any person" under § 2(c) and whether the Broch transaction was the type covered under this section.The entire Court agreed that a seller's broker was covered by the section. 363 U.S. at 170,179 . However, the dissenters posited that this transaction between the seller and his broker was not within the purview of $\S 2$ (c), arguing that the reduction of brokerage merely represented a renegotiation of rate charged the seller and not paying of "anything of value as a commission, brokerage, or other compensation," or an "allowance or discount in lieu thereof" to the buyer, who was the target of the seetion. Id. at 179-84. Further, the dissent contended that a deeision proscribing the renegotiation of the brokerage payments between a seller and his independent broker would freeze brokerage rates by establishing the first negotiated rate as an irrevocable floor. Id. Finally, the dissenters, noting the Court's limitation of the holding to discriminatory situations, see note 28 supra and accompanying text, contended that the majority had either tacitly tested the case under $\$ 2$ (a) standards, the seetion the minority considered applicable, and found no cost justification or had "weakened. . . the per se thrust" by reading a discriminatory element into $\$ 2$ (c). Id. at 188-89. However, the majority ruled that this seller's broker's reduetion fell within the 2(c) proscriptions since such a reduction was necessary for the subsequent price reduction to the buyer from the broker. Id. at 175 . Thus, Broch became the first decision to bring the seller's broker under § 2(c). Sce Comment, 10 DePaul L. Rev. at 8I; Comment, 28 U. Chi. L. Rev. at 512.

30 "This is not to say that every reduction in price, coupled with a reduction in brokerage, automatically compels the conclusion that an allowance 'in lieu' of brokerage has been granted. As the Commission itself has made clear, whether such a reduction is tantamount to a discriminatory payment of brokerage depends on the circumstances of each case." 363 U.S. at 175-76 (1960). Sce note 28 supra.

${ }^{31}$ The Court concluded that "there is no evidence that the buyer rendered any services to the seller or to the respondent nor that anything in its method of dealing justified its getting a discriminatory price by means of a reduced brokerage charge. We would have quite a different case if there werc such evidence and we nced to explore the applicability of $\S 2$ (c) to such circumstances." 363 U.S. at 173. This implied qualification upon the proscription of the brokerage clause, inferring possible justifications for discrimination, has become the basis for subsequent decisions allowing "services rendered" and "cost-savings" defenses. See Rill, note 26 supra, at 346-54. See notes 34-68 infra and aecompanying text.

${ }^{32}$ See note 28 supra.

"Prior to the decision in Broch, it had been asserted that "the hrokerage clause was the only section as to which no important question of interpretation still remains unsettled." AustrN, at 
Although it has been contended that the construction is strained, ${ }^{34}$ there are indications that a significant effect of the Broch dicta has been a revitalization of the "services rendered" exception. Apparently accepting "services rendered" as a criterion for determining whether a discriminatory payment or discount in lieu of payment is justified, ${ }^{35}$ the FTC has condoned discounts in several cases where the seller has established that the compensation had been earned through the buyer's performance of storage, warehousing and distribution services with regard to the seller's product. ${ }^{36}$ However, the Commission has attempted to avoid a direct confrontation with the traditional precedents forbidding buyer-seller payments ${ }^{37}$ by the development of some contextually unique rationales. Thus, in Flotill Products, Inc. ${ }^{38}$

106. Conversely, since Broch, little consensus exists as to the nature of section 2(c)'s prohibitions. See Rowe at 330 .

"See Bison, note 20 supra, at 330.

${ }^{35}$ In Garrett-Holmes \& Co., [1963-1965 Transfer Binder] Trade Reg. Rep. I 17,209 at 22,279 (FTC 1965), the FTC affirmed a cease and desist order entered against a food broker who had accepted brokerage or discounts in lieu of brokerage from suppliers with regard to purchases for the broker's own account for resale. Following the Broch dicta, the Commission reasoned that " $[t]$ here is no evidence that the buyer rendered any services to the seller(s) ... nor that anything in its method of dealing justified its getting a 'discriminatory pricc' as 'brokerage' or discounts in lieu thereof. [Thus,] [t]he examiner was correct in concluding that the payments received by the respondent violated section 2(c) of the Clayton Act, as amended." Id. at 22,280. Moreover, the Commission has disallowed a cease and desist order against a buyer that had been given discriminatory price reductions "in lieu of brokerage" because the discount was for distributive services. Hruby Distrib. Co., 61 F.T.C. 1437 (1962). In Hruby, the Commission emphasized the respondent's need to be compensated in order to compete with independent brokers, id. at 1448 , indicating, perhaps, a receptiveness to a "meeting competition" defense under 2(c). Finally, in Flotill Prods., Inc., [1963-1965 Transfer Binder] TRADE Reg. Rep. I 16,970 at 22,032 (FTC 1964), a cease and desist order against a canned goods supplier who had granted discriminatory prices to certain buycr-brokers was reversed. In a separate opinion, Commissioner Elman noted that "the common characteristic of all transactions prohibited by $2(\mathrm{c})$ is that brokerage or other legitimate and valuable services in distribution are not performed." Id. at 22,046. Thus, only "[s]purious, false, unearned brokerage is forbidden; but if a businessman performs a valuable and substantial service or function in the distribution of goods, he is entitled to be compensated for it, and section 2(c) does not apply . . . . That is so even if he is not a conventional brokcr yet performs services which in other situations are performed by brokers." Id. Commissioner Elman further emphasized both the necessity of compensation for these services and that the presence and use of this method of distribution was essential to the survival of the small businesses in the canning industry. Id. at 22,047. See generally Rill, note 26 supra, at 341-54; Comment, 42 N.C.L. Rev. 457 (1964).

${ }^{36}$ Flotill Prods., inc., [1963-1965 Transfer Binder] TRADE Reg. Rep. If 16,970 at 22,032

(FTC 1964); Hruby Distrib. Co., 61 F.T.C. 1437, 1443 (1962). Sce note 35 supra.

${ }^{37}$ See notes 22-25 supra and accompanying text.

38 [1963-1965 Transfer Binder] TrADE REG. REP. If 16,970 at 22,032 (FTC 1964). 
the Commission found that brokerage had not been realized since "actual title" did not pass to the broker ${ }^{39}$ and in Hruby Distributing Co. ${ }^{40}$ held that the apparent brokerage was a "functional discount," not cognizable under section 2(c)..$^{41}$ Nevertheless, the implication of the FTC decisions is that where possible the Commission will remove alleged brokerage from the purview of section 2(c) on the ground that the discounts granted were neither "dummy brokerage," since valuable services in distribution were rendered, nor savings attained through the seller's reduction of ordinary brokerage services. ${ }^{42}$

${ }^{39}$ The Commission attempted to avoid the absolute ban upon brokerage payments to buyers by deciding that "actual" title had not passed to the brokers, although "technical" title may have been transferred. The Commission reasoned that the recipient of "actual title" determined the identity of the "other party" to a sales transaction for whom it was illegal to receive brokerage. Id. at 22,036. Although the brokers in the case were billed and paid for the goods, admitted to ownership, and exercised substantial control over the articles in distribution, they were held not to have "actual ownership" because they never gained possession. Id. Thus, the Commission stated that "[v]iewed as a part of the entire transaction from the time of the placing of the order by the ultimate purchaser until the delivery of the goods to him, we find that technical title passage, if such be the case, would not be conclusive but would be merely incidental to the services performed by the field broker for the canner." Id. at 22,037.

This confusing rationale was criticized, however, in Commissioner Elman's separate opinion: "The chairman's opinion reaches the right result . . . by a curious route . . . [for] to make legality depend upon whether his title is 'incidental' or 'absolute' is to introduce irrelevant and confusing standards into a law designed to deal with the realities of commercial transactions, not their superficial forms." The Commissioner then proposed his alternative rationale, advising that "the Commission no longer accepts the dogma that section 2(c) forbids, in any and all circumstances, the payment of compensation in the form of brokerage for services rendered by a seller to a purchaser or by a purchaser to a seller" and that this case was one in which section 2(c) did not apply. Id. at 22,048. Sec Elman, note 18 supra, at 23-25.

${ }^{10} 61$ F.T.C. 1437 (1962).

11 The Commission held that the practice of the buyer-broker in receiving brokerage was not within the purview of 2 (c), but was a functional discount to be considered under section 2(a). Id. The Commission reasoned that the buyer operated at a functional level between the producer of goods and the wholesaler to whom he sold. Since the respondent was at a higher functional level than a wholesaler, his lower price was considered a functional discount and not a result of savings in brokerage. Id. at 1448. See generally Rowe at 341-42.

The dissent of Commissioner Maclntyre points out that this argument previously had been made and rejected in Southgate Brokerage Company v. FTC, 150 F.2d 607 (4th Cir. 1945), and that that decision is still applicable to buyers purchasing for their own account. Id. at 1455 . The dissent also noted that the Commission's ruling might be interpreted as fusing section 2(a) and section 2(c) by allowing a price discrimination betwecn non-competitive functional levels tbat previously had been allowed only in section 2(a) cases. Id. at 1455. But see notes 138-67 infra and accompanying text. Sec Comment, 42 N.C.L. REv. 457, 466-67 (1964), and notes 54-66 infra and accompanying text, for an analysis of this fusion as a logical development of the BrochThomasville Chair decisions. See also Rill, note 26 supra, at 346-54.

42 "Hruby is clearly not a 'dummy' broker controlled by a large buyer to whom he passes on phony brokerage payments. Equally clearly, he is not himself a powerful wholesaler or retail 
Consequently, the legitimacy of these discounts would be challengeable only under the section 2(a) ban upon direct price discrimination. ${ }^{43}$ Since the defendant would have the advantage of the statutory defenses there available, the FTC has thus at least partially debilitated the absolute prohibition of seller-buyer brokerage payments. $^{44}$

The procedure of mitigating the proscription of the brokerage clause by restricting the scope of its application has also received judicial endorsement. Condoning a seller-buyer discount, ${ }^{45}$ the Court

chain exacting from his suppliers false brokerage payments, to the competitive disadvantagc of his smaller competitors. And, finally, it is clear that the discounts received by Hruby are not granted because on sales to him sellers could dispense with brokerage services regularly required on their sales, thus effecting savings of usual brokeragc fees." Hruby Distrib. Co., 61 F.T.C. 1437, 1447-48 (1962). In Flotill Prods. Co., [1963-1965 Transfer Binder] Trade Reg. Rep. I] 16,970, at 22,032 (FTC 1964), Commissioner Elman stated that section 2(c) did not proscribe "legitimate, bona fide transactions . . . but strictly . . . phony, unearned brokerage." Id. at 22,046 .

${ }^{43}$ See notes 38-41 supra.

"Recent decisions have not contributed to a clarification of the FTC's position concerning the "services rendered" defense. In recent cases involving an independent broker's secret rebates to buyers of part of its brokerage receipts from sellers, e.g., Connell Rice \& Sugar Co., 3 TRADE REG. REP. T 17,948 (May 8, 1967), in cases where brokers havc passed along receipts through financing the buycr's promotional programs, e.g., Allianee Associates, Inc., 3 TRADE REG. REP. I 18,309 (May 20, 1968); Modern Mktg. Servs., Inc., 3 TRADE Reg. ReP. I 17,945 (April 17, 1967), and in the classical situation of a seller's payments of brokerage to a buyer's broker, e.g., A. Grecnhouse, Inc., 3 Trade Reg. ReP. If 17,940 (April 27, 1967) (consent order), no attempts were made to advocate the "services rendered defense."

4s Empire Rayon Yarn Co. v. American Viscose Corp., 364 F.2d 491 (2d Cir. 1966), cert. denied, 385 U.S. 1002 (1967). In the original litigation, the District Court for the Southern District of Ncw York awarded a summary judgment to a respondent charged with giving discounts "in lieu of" brokerage. A manufacturer had sold at discount to the respondents, two rayon processors, who acted as jobbers for the manufacturer. The respondents argued that this diseount was justified because the manufacturer's costs were lower in selling through these jobbers than they would have been if sales were made directly to small buyers. Accepting the respondent's position, the court ruled that the "serviees rendered" defense was available to the respondents even though the jobbers who performed the serviee were buyers. Empirc Rayon Yarn Co. v. American Viscose Corp., 238 F. Supp. 556, 560 (S.D.N.Y. 1965). On appeal, the Court of Appeals for the Second Circuit reversed the summary judgment for the respondent, assuming the traditional position that the charaeter of the respondents as buyers made them incapable of rendering serviees to the seller because of a confliet in interest. Empire Rayon Yarn Co. v. American Viscose Corp., 354 F.2d 182 (2d Cir. 1965) (2-1 decision); see 34 GeO. Wash. L. REv. 808 (1966). In the well-reasoned dissent to this decision, Judge Moore argued that the majority had erred in banning discounts given to buycrs as compensation for serviees rendered since such a proscription would expand the brokerage section beyond its intended scope. 354 F.2d at 188-89. Judge Moore emphasized that the services rendered by the buyer were necessary in order to enable the seller to reach markets in which he would otherwise have been unable to compete. Id. at 190, 191. Upon rehearing en banc, the Second Circuit, accepting the rationale of Judge Moore's dissenting opinion, reversed its decision by ruling that the respon- 
of Appeals for the Second Circuit reasoned, as has the Commission, that it would be an improper expansion of section 2(c)'s "language and manifest purpose" 46 to encompass within its prohibition anything but "dummy brokerage" or discounts arising because fewer brokerage services were needed for sales to the recipient buyer. ${ }^{47}$ Thus, noting that the buyer had provided inventory maintenance, advertising ${ }^{48}$ and a selling organization, the court found the discount justifiable as compensation for "services rendered" and therefore outside the purview of section 2(c) ${ }^{49}$ Although these decisions indicate the developing legality of service-related discounts, it is likely that both the courts and the Commission will require that there be a reasonable relationship between the amount of brokerage or discount and the nature of the services to the seller since brokerage payments disproportionate to the value of the services would be partially unearned and consequently violative of section 2(c). ${ }^{50}$ Arguably, a practical method of determining reasonableness of compensation would be through comparison between the brokerage granted to the seller and that demanded by an independent broker for like services.

Although clearly inconsistent with traditional doctrine, the decisions sustaining seller-buyer brokerages for services rendered find substantial support both in the text of section 2(c) and in its legislative history. The congressional report on the Robinson-Patman amendments $^{51}$ and the comments of those who drafted the legislation ${ }^{52}$

dents' activities did not violate section 2(c). The court stressed that since the buyer performed a necessary economic function for the seller, the compensatory discount should not be proscribed under $\S 2$ (c). Empire Rayon Yarn Co. v. American Viscose Corp., 364 F.2d 491 (2d Cir. 1966), cert. denied, 385 U.S. 1002 (1967).

46 354 F.2d at 191. But see notes 5-6 \& 28 supra and accompanying text.

${ }^{47} \mathrm{Id}$. See notes 60-72 infra and accompanying text for a discussion of savings in brokerage as a basis for justifying a discriminatory payment of discount.

48 The jobber-brokers performed services in the "maintenance of substantial inventories of yarn in their plants as well as in warehouses, maintenance of an experienced selling organization, ... advertising [seller's] products ... and furnishing technical assistance to users of [product]." 354 F.2d at 183-84.

$\$ 364$ F.2d at 492. As in Hruby, see notes 40-42 supra, the court attempted to superficially distinguish a "functional discount." Id. However, the approval of the discount given the buyer's brokers seems to have been based upon the performance of distributive services for the seller. See J. Moore's dissenting opinion, 354 F.2d at 191, discussed in note 45 supra.

${ }^{\text {so }}$ As indicated in Flotill Prods. Co., [1963-1965 Transfer Binder] Trade Reg. ReP. ๆ 16,970, at 22,032 (FTC 1964), brokerage payments disproportionate to the value of the services to their recipient would be an illegal variation of "dummy" brokerage. See note 42 supra.

sI See note 6 supra.

${ }^{32}$ See note 6 supra. 
indicate that Congress intended payments of earned brokerage to be allowed under the brokerage clause, regardless of the relationship of the parties rendering and receiving the services. Most importantly, the text of section 2(c) contains no limitation upon the "services rendered" exception..$^{53}$ Moreover, revitalization of the services rendered provision makes the application of section 2(c) more consistent with the generally acknowledged purpose of antitrust legislation: protection of free and, insofar as is practical, unlimited competition. ${ }^{54}$ Thus, acceptance of the "services rendered" defense destroys the monopoly otherwise granted to independent brokers ${ }^{3 s}$ and encourages beneficial competition in the distributive channels ${ }^{56}$ by permitting any party to perform and be compensated for brokerage services. ${ }^{57}$ Finally, it is arguable that allowing seller-buyer brokerage payments will not eviscerate the efficacy of the brokerage clause's

\footnotetext{
${ }^{33}$ See note 4 supra.

${ }^{34}$ See ATT'Y GEN. REP. at 190-93; Elman, note 18 supra, at 23-25. In oral arguments to Siandard Oil Co. v. FTC, 340 U.S. 231, 249 (1951), Mr. Justice Jackson, quoted in Oppenheim, note 21 supra, at $1199 \mathrm{n} .158$, commented upon the soft competition rationale of the RobinsonPatman Act: "[T]he whole philosophy of the Sherman Act is go out and compete, get business, fight for it. Now, the whole philosophy we are asked to enforce here is that you really must not, you let this business go and not meet the competition. I bave difficulty knowing where we are with this . . . O"Oppenheim has criticized tbis "soft competition" as "a crutch to the inefficient in the economy," id. at 1201, and suggests a revision of the present Act. See note 84 infra.

ss See notes 24-25 supra and accompanying text.

${ }^{36} \mathrm{~A}$ desirable effect of increased competition in brokerage distribution may be decreased consumer prices througb enhanced distribution cfficiency. As stated by Rowe, the result of an absolute prohibition upon buycr-seller brokerage was "that Section 2(c) [became] a featherbedding guarantee for the organized food brokers aboard a legal gravytrain-at the expense of cost-cutting forms of distribution." RowE at 540. See, e.g., ATT'Y GEN. REP. at 190-9I; Mọssel, Competition and Monopoly 55 (1962); Neale, The Antitrust laws of THE U.S.A. 169 (1960).

${ }^{37} \mathrm{~A}$ consistent rationale for the decisions that have thus far accepted services rendered as a justification for brokerage payments between buyers and sellers has been the economic necessity and/or value of the services performed by the buyer-brokers. Thus, in Flotill Prods., Inc., [19631965 Transfer Binder] TRADE REG. REP. If 16,970, at 22,047-48 (FTC 1964), it was emphasized that the use of buyer-brokers was essential in order for small sellers to survive and cffectively compete with larger sellers. Hruby Distrib. Co., 61 F.T.C. I437, 1446 (1962), assumes that a buyer may compete witb independent brokers and, therefore, requires that he must receive compensation. Moreover, Judge Moore's dissenting opinion in Empire Rayon Yarn Co. v. American Viscose, 354 F.2d 182 (2d Cir. 1965), subsequently adopted as a basis for reversal by the Second Circuit in Empire Rayon Yarn Co. v. American Viscose, 364 F.2d 491 (2d Cir. 1966), cert. denied, 385 U.S. 1002 (1967), see note 45 supra, noted that the seller could not have reached the ultimate buyers of a particular sector of the market had the intermittant buyerbroker not been used. 354 F.2d at 190 . These decisions clearly recognize that market participants other than professional brokers can adequately perform brokerage services and, in certain situations, must perform those services in order to achieve effective competition.
} 
preclusion of unjustified price discrimination, as feared by courts initially construing the provision. ${ }^{58}$ As indicated by the recent decisions, "fraud and oppression" 59 may be effectively avoided by careful scrutiny of the evidence to ascertain whether valuable brokerage services were actually performed and if the brokerage payments were no more than a reasonable compensation for such services.

In further mitigation of the section's dissolute proscription, several courts have gone beyond mere restoration of the "services rendered" defense by accepting cost-savings as a justification for discriminatory brokerage payments or discounts, thus debilitating the doctrinal precept that price differentials effecting reduced brokerage fees constitute allowances "in lieu of brokerage" violative of section 2(c). Relying upon the "discrimination" emphasis of the Broch dicta ${ }^{60}$ the Court of Appeals for the Fifth Circuit has held that an alleged violator may avoid section 2(c) liability by demonstrating that a discount merely reflected bona fide differences in cost of sales to the recipient buyer resulting from differing methods or quantities in which commodities are sold or delivered. ${ }^{61}$ Thus, despite the FTC's rejection of the position, ${ }^{62}$ the Fifth Circuit would apparently allow the defendant to establish the same type of cost justification, through the same empirical studies, as is required to avoid section 2(a).$^{63}$ Although the Fifth Circuit directly addressed price differentials

ssee notes 16 \& 21 supra.

s9 Great Atl. \& Pac. Tea Co. v. FTC, 106 F.2d 667, 674 (3d Cir. 1939), cert. denied, 308 U.S. 625 (1940).

${ }^{\circ}$ See notes $28-31$ supra and accompanying text.

${ }^{61}$ Thomasville Chair Co. v. FTC, 306 F.2d 541 (5th Cir. 1962). In Thomasville Chair, a manufacturer of furniture allegedly violated $\S 2$ (c) by giving a discount to customers who purchased a certain amount of goods and by giving his salesmen a lower commission upon sales to these customers. The Commission had ruled that this reduction of price coupled with a reduction of commission was a violation of section 2 (c).

However, the Fifth Circuit held that if the respondent could introduce evidence showing a difference in the cost of dealing with the different customer groups, section 2(c) could be avoided. The hasis of this deeision was a liheral interpretation of the Broch dicta: "[A]s we read it, the [Broch] opinion says that a reduction in price, giving effect to reduced commissions paid by the seller, are violations of Seetion 2(c) only if such reduction in price is 'discriminatory.' We read that to mean 'without justification based on actual bona fide differences in the cost of sales resulting from the differing methods or quantities in which such commodities are sold or delivered." "Id. at 545. See generally Comment, 42 N.C.L. Rev. 457 (1964); 5 I CALIF. L. Rev. 215 (1963); 43 B.U.L. Rev. 427 (1963); 30 Geo. WASH. L. Rev. 137 (1961); 13 SyRacuse L. REV. 147 (1961).

62 See BNA ANtitrust \& Trade Reg. ReP. A-I1 (No. 120, Oct. 29, 1963).

${ }^{63}$ According to Thomasville Chair, it is necessary that "the Commission . . . permit a full 
ensuing from savings reflecting partial reductions in brokerage fees, the rationale would arguably extend to savings resulting from total non-payment of commissions on sales where such services are unnecessary.$^{64}$ Further, the Court of Appeals for the Seventh Circuit has accepted a cost-savings defense to the brokerage clause dissimilar to section 2(a)'s defense both in the type of cost-savings allowed and

scale inquiry into the propriety of the [discounts] based upon the [cost] differentials permitted under Section 2(a) . . . " 306 F.2d at 545. See generally RowE, at 287-90. To successively achieve cost-justification in $\S 2$ (a) litigation, the respondent is generally required to produce an independent cost study precisely establishing the actual savings redounding to the grantor of the price reduction. See, e.g., Automatic Cantecn Co. v. FTC, 346 U.S. 61,68 (1953); Curtiss Candy Co., 44 F.T.C. 237, 267 (1947). Further, the studies are required to be conducted with reference to only the parties involved and the cost-savings of the individual transaction are required to be shown. Cf. Standard Oil Co., 41 F.T.C. 263 (1945). However, this individual transaction basis has been recognized as impractical and there is authority for allowance of group and average studies if they are made by an independent group and follow accepted accounting principles. See United States v. Borden Co., 370 U.S. 460 (1962); American Motors Corp. v. FTC, 384 F.2d 247 (6th Cir. 1967); FTC v. Standard Motor Prods., Inc., 371 F.2d 613 (2d Cir. 1967); American Can Co. v. Russelville Canning Co., 19I F.2d 38, 59-60 (5th Cir. 1951); Minneapolis Honeywell Regulator Co., 44 F.T.C. 351 (1948), rev'd on other grounds, 191 F.2d 786 (7th Cir. 1951), cert. denied, 344 U.S. 206 (1952). Nevertheless, the cost and difficulty of compiling the studies-Minneapolis Honeywell's cost study occupied four to eight accountants for nine months-have led commentators to consider the defense as illusory except for the most prosperous. See ATT'Y GEN. REP. 173-74; Adelman, The Consistency of the Robinson-Patman Act, 6 STAN. L. REv. 3, 9 (1953). See generally. Rowe at ch. 10; Blackford, supra note 10, at 299-300; Mayer, supra note 10, at 314-16.

${ }^{6}$ Both the Commission and Courts early took the position that the reduction or climination of brokerage cost to a seller does not justify a brokerage payment or "discount in lieu thereof' to the buyer. See, e.g., Southgate Brokerage Co.v. FTC, 150 F.2d 607 (4th Cir. 1945); Great Atl. \& Pac. Tea Co. v. FTC, 106 F.2d 667 (3d Cir. 1939), cert. denied, 308 U.S. 625 (1940); Union Mallenisle Mfg. Co., 52 F.T.C. 408 (1955); Custom House Packing Corp., 43 F.T.C. 164 (1946); W.E. Robinson \& Co., 32 F.T.C. 370 (1941); Ramsdell Packing Co., 32 F.T.C. 1187 (1941). However, as noted by the dissenters in FTC v. Henry Broch \& Co., 363 U.S. 166, 182-87 (1960), there are indieations within the legislative history of the Act that such brokcrage savings were to be allowed to cost justify lower prices, for a provision that would have specifically denied such reductions or eliminations in brokerage cost as cost justifications under section 2(b), $S$. REP. No. 1502, 74th Cong., 2d Sess. 5 (1936), was deleted from the bill. H.R. CoNF. REP. No. 2951, 74th Cong., 2d Sess. 6 (1936). Further, the allowance of such savings as cost justifications under section 2(b), the section applied under the Thomasville case, see note 63 stupra and aecompanying text, was condoned upon the Senate floor. 80 CoNG. REC. 6285 (1936). However, although several circuits have indicated their receptiveness to this position, see Thomasville Chair Co. v. FTC, 306 F.2d 541 (5th Cir. 1962); Robinson v. Stanley Homes Products, Inc., 272 F.2d 601 (1st Cir. 1959); $c f$. Central Retailer-Owned Grocers, Inc. v. FTC, 319 F.2d 410, 414 (7th Cir. 1963), and the leading commentator in the area has cogently argued that the acceptance of reduced or eliminated brokerage costs would eliminate featherbedding by independent brokers, Rowe at 290, the Commission, see Advisory Opinion Digest No. 243, 3 TRADE REG. REP. If 18,334 (May 7, 1968), and most circuits, see FTC v. Washington Fish \& Oyster Co., 282 F.2d 595 (9th Cir. 1960), continuc to consider payments or "discounts in lieu thereof' caused by reduced brokerage costs as violative of section 2(c). 
the method of establishing those savings. ${ }^{65}$ Recognizing cost-savings based upon factors such as the buyer's advance commitments and low credit risk reducing the speculative element of sale, ${ }^{66}$ the court did not require that actual cost-savings be precisely shown through independent cost studies as is axiomatically required in section 2(a) litigation. ${ }^{67}$ Rather, the mere identification of certain characteristics of the transaction, which presumably gave rise to an unascertained amount ol savings to the seller was required by this court. ${ }^{65}$

The dissenters in Broch had early foreseen that the Court's dicta might be interpreted as fusing the direct price discrimination provisions of section 2(a) with the brokerage clause by indicating that defenses to the former section, such as cost-justification, would be effective in avoiding section 2(c).$^{69}$ Although failing to accomplish precisely such a fusion, it seems clear that the interpretations of the Broch dicta promulgated by the Second and Seventh Circuits ultimately contradict the legislative intent that no defense other than "services rendered" be available to those charged under section 2(c)..$^{70}$ Moreover, the effect of so extending the substance of the cost-savings defense may be to frustrate the Robinson-Patman Act policy of

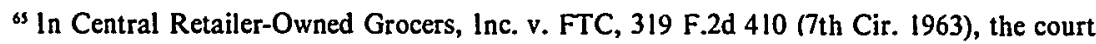
reversed a cease and desist order entered against a cooperative buying association, totally owned by small retail grocers, restraining it from accepting discounts and services payments upon its purchases. The cooperative involved bought from suppliers for its members upon the members' estimates of their yearly needs, charged the members cost plus for the products thus obtained, and distributed any "profit" to member stores at the end of the year. Price concessions were induced from their suppliers by promising that the suppliers would realize savings in their dealings with Central because of its ". . . advance commitments from its mcmbers, the lack of credit risk, the fact that the suppliers need look to only one central office for payment . . ., and the fact that Central supplies its own labels." Id. at 413 . Ruling that these activities did not constitute a violation of $\S 2$ (c) merely because the amount of discount corresponded to the amount of brokerage, $i d$. at 414, the court echoed Thomasville Chair Co. v. FTC, 306 F.2d 541 (2d Cir. 1962), by indicating that the Commission has the burden of showing a causal connection between the redueed priee and reduced or eliminated brokerage expenses. Id. at 415 .

${ }^{66}$ The court found there to be legitimate cost justifications due to the respondent's volume of business, lack of credit risk, lower billing costs, advance commitments, and supply of a private label for its products. 319 F.2d at 413 . Further, while not attacking precedent, see note 65 supra, by relying upon this characteristic, the Court noted that no brokerage expenses were incurred upon Central's privately-branded products. Id. at 414 .

${ }^{67}$ See note 63 supra.

${ }^{63}$ See note 66 supra. The obvious danger of this lenient procedure is that it makes impossible the comparison of actual saving and actual discount. Such a comparison prevents excessive price reductions based upon small cost savings.

${ }^{69}$ See note 29 supra.

${ }^{70}$ See note 6 supra and authority cited therein. 
providing protection for the smaller buyer's market position. ${ }^{71}$ Since the types of cost-savings recognized by these decisions are primarily those caused by economics of scale-lower unit costs at higher volumes $^{72}$ - the large buyer will be the most common recipient of such "legitimate" discounts.

However, the competitive disadvantage caused the small buyer by the extension of a cost-savings defense to section 2(c) seems primarily illusory since some small buyers may take advantage of the same economies of scale by organizing into larger cooperative buying units. ${ }^{73}$ Also, there is no apparent reason why the extension of this defense to indirect price discrimination would favor the large buyer more than the latter is already favored by the judicially sanctioned application of the cost-savings defense in direct price discrimination cases. Further, the apparent contradiction of Congressional intent in accepting a cost-savings defense to section 2(c) charges may be justified by the ultimate economic effect, the reduction of price to the consumer resulting from the buyer's ability to "pass along" savings that would otherwise have been enjoyed by the seller in the lorm of a higher profit margin. ${ }^{74}$ Thus, this extension of the cost-savings defense may ultimately represent the long advocated rejection of the

\footnotetext{
"The Robinson-Patman Act is not exclusively an antitrust statute aimed only at protecting competition. Rather, the Act encourages "soft competition," serving dual purposes of preserving competition and protecting the competitive position of the individual competitor. See Oppenheim, note 21 supra, at 1198-1202. However, it is contended that, in providing this statutory protection for individual competitors, the "inefficient and laggard firms" who would otherwise be driven out by market pressures, are allowed to remain in the economy. See id. at 1201; Blackford, A Survey and Commentary on the Good Faith Meeting of Competition Defense in the Robinson-Patman Act, 18 W. REs. L. REv. 753, 775 (1967). Also, this legislative preference for the "little man" reflects the outdated, Victorian belief that bigness is evil per se while the "small businessman ... [ [has the] virtues that are held in esteem in a capitalistic society." Id. at 777. See note 84 infra and accompanying text.

${ }^{72}$ See Central Retailer-Owned Grocers, Inc. v. FTC, 319 F.2d 410 (7th Cir. 1963). See also FTC v. Morton Salt Co., 334 U.S. 37 (1948); Thompson Prods., Inc., 55 F.T.C. 1252 (1959); Hamburg Bros., 54 F.T.C. 1450 (1958); Standard Oil Co., 41 F.T.C. 263 (1943).

${ }^{7}$ See Central Retailer-Owned Grocers, Inc., 319 F.2d 410 (7th Cir. 1963). However, all buyers in many industries may not be able to adequately organize since physical distance hetween buyers, for example, might effectively negate attempts to form cooperatives. Also, the time and expense of organizing such organizations might be prohibitive to the smaller buyers. Finally, the relative efficiency of such cooperatives might be lower than that of the "professional" broker buyer so as to reduce anticipated cost-savings.

"See Note, 51 CALIF. L. Rev. 215, 219 (1963). See also Oppenheim, Federal Antitrust Legislation: Guideposts to a Revised National Antitrust Policy, 50 MicH. L. Rev. 1139, 1202 (1952). The Seventh Circuit has approved the "worthy effort" of buyers' cooperatives to reduce the ultimate price to the consumer. See Central Retailer-Owned Grocers, Inc. v. FTC, 319 F.2d 410, 414-15 (7th Cir. 1963).
} 
statutes' use to protect less efficient small buyers from competitive market pressures and promote the consumer's interest in an efficient economy. ${ }^{75}$

To date, neither the Commission nor the courts have gone so far as to extend a meeting competition, ${ }^{76}$ lack of knowledge, ${ }^{77}$ or competitive injury defense ${ }^{78}$ to section $2(c)$. Therefore, in order to take advantage of these defenses, a defendant charged with a RobinsonPatman violation must establish that his activities were without the scope of section 2(c) and within the purview of section 2(a). The Broch dissent indicates that this may be accomplished by showing that the recipient party neither claimed nor received, directly or through an intermediary, brokerage, allowance, or reduction of price as compensation for alleged distributive services rendered. ${ }^{79}$ Although this argument is as yet untested before either the Commission or the judiciary, it may safely be predicted that if the term "brokerage" has been used in describing payments or discounts, a subsequent denial will be ineffective in avoiding the harsh prohibitions of the brokerage clause. ${ }^{80}$

\footnotetext{
"See ATT'Y GEN. REP, at 192; Oppenheim, note 74 supra, at 1201.

${ }^{76}$ See notes 173-90 infra and accompanying text. However, in Hruby Distrib. Co., 61 F.T.C. 1437 (1962), the Commission emphasized the buyer's need to gain compensation for his services in order to compete with independent brokers, although this necessity was not discussed in terms of a "meeting competition" defense. Id. at 1448 .

$n$ Although no holding has allowed a buyer or seller to avoid $\S 2$ (c) because of a lack of knowledge of the proscribed activity or an absence of intent to commit the proscribed activity, there have been indications by the Commission and courts that knowledge may be a relevant consideration in determining violation of the section. Thus, a seller's violation of 2 (c) has becn characterized as allowing payments to brokers with the knowledge that such payments were being passed along to the buyers. See, e.g., Great Atl. \& Pac. Tea Co., 26 F.T.C. 486, 501 (1938), affd, 106 F.2d 667 (3d Cir. 1939), cert. denied, 308 U.S. 625 (1940); Oliver Bros. v. FTC, 102 F.2d 763 (4th Cir. 1939); Biddle Purchasing Co. v. FTC, 96 F.2d 687, 689 (2d Cir. 1938); Exchange Distrib. Co., 61 F.T.C. 1, 6 (1962); Haines City Citrus Grocers Ass'n, 58 F.T.C. 815 (1961). Contra, Western Fruit Growers Sales Co. v. FTC, 332 F.2d 67, 68 (9th Cir. 1963); National Retail-Owned Grocers, Inc., 60 F.T.C. 1208 (1962); Eidson Produce Co., 60 F.T.C. 1, 5-6 (1962). Moreover, Broch, with characteristic ambiguity, indicated that a buyer's intent (or knowledge) might be material if he is charged with receiving an allowance that violates $\$ 2$ (c). 363 U.S. at 174. Consequently, it has been argued that no culpability will be attached to a party unless he has reason to suspect that the activity is violative of $\S 2$ (c). Rowe at 347. Contra, Comment, 28 U. CHI. L. REv. at 515 . However, there seems to be general agreement that neither intent nor scienter need be proved to achieve a brokerage-clause violation. See, e.g., Note, 41 Notre Dame Law. 355, 362 (1966).

"See notes $169-72$ infra and accompanying text.

79363 U.S. at 180, 182; cf. Empire Rayon Yarn Co. v. American Viscose Co., 364 F.2d 491 (2d Cir. 1966), cert. denied, 385 U.S. 1002 (1967); Hruby Distrib. Co., 61 F.T.C. 1437 (1962).

${ }^{80}$ It would be inconsistent with the purposes of $\S 2(\mathrm{c})$, see notes 5-6 supra and accompanying text, to allow parties who have attempted to conceal actual price discrimination in the guise of
} 
Since Broch, there is an apparent trend away from an interpretation of the brokerage clause proscriptions as absolute. Judicial and enforcement-agency acceptance of effective defenses to section 2(c) seems to indicate a growing recognition of the economic necessity for alternative methods of distribution..$^{81}$ However, it would be misleading to infer that the defendant charged with a brokerage clause violation may now present these defenses with a certainty that either the Commission or all courts will be sympathetic to his arguments. The numerous cases holding that seller-buyer discounts are invalid per se have not been directly overruled, and there has been an obvious reluctance upon the part of courts and the FTC to challenge this "traditional" position. ${ }^{82}$ Consequently, unless the Supreme Court overrules the absolute interpretation ${ }^{83}$ or Congress amends the section ${ }^{84}$ the outcome of section 2(c) litigation will be determined primarily by the willingness of the forum to ignore, or superficially distinguish, precedent in favor of the compelling economic rationale of the defenses. Moreover, the few cases accepting defenses to the brokerage clause have been less than informative as to

brokerage to utilize the more extensive and well-defined defenses to section 2(a) by admitting that their "brokerage" was a sham. Arguably, this treatment may result in some unnecessary harshness in the treatment of an inane businessman who does not realize the consequences of brokerage terminology, see Hruby Distrib. Co., 61 F.T.C. 1437, 1449 (1962), but the restriction nevertheless seems necessary to effect the purpose of the section in discouraging hidden price discrimination. See note 18 supra and accompanying text.

"See notes 24, 25, 74 supra and accompanying text.

'See notes 38-41 supra.

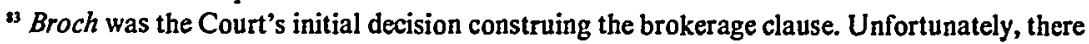
has been no significant subsequent litigation and there are no section 2 (c) cases presently pending before the Court.

"It has been suggested that the entire Robinson-Patman Act should be revised to make it consistent with $\S 5$ of the Federal Trade Commission Act, 15 U.S.C. $\S 45$ (1964), and $\S \S 3$ and 7 of the Clayton Act, 15 U.S.C. $\$ \S 14 \& 18$ (1964), to better align the Act with "national antitrust policy." Oppenheim, note 74 supra, at 1201. Oppenheim suggests that the proscriptions of $\S 2$ should be applied only if the effect of discrimination is to substantially lessen competition or to create monopoly. Further, the modified statute would favor "hard competition" by sanctioning discrimination if justified on the basis of cost-savings, good faith meeting of competition, or "other legitimate economic justifications in the distribution system . . . " Id. at 1202. Sections 2(c), (d), and (e) would be eliminated as all forms of illegal rebates could bc included within the interpretation of "price." Brokerage payments would be valid if made for actual and bona fide services rendered, regardless, apparently, of the relationship of the parties. Id. at 1206-07. See also ATT'Y GEN. REP. More recently, Commissioner Elman has also called for a reappraisal of the traditional interpretation and application of $\$ 2(c)$ against buyer-seller brokerage payments. Elman, The Robinson-Patman Act and Anti-Trust Policy: A Time for Reappraisal, 42 WasH. L. Rev. 1, 24-25 (1966). 
the constituent elements necessary to present an effective defense. ${ }^{85}$ The type of services that are mandatory for the "services rendered" defense have not been succinctly described, nor have the criteria to be used in determining whether the compensation for such services is reasonably proportional to their value been adequately delineated.$^{86}$ The elements of a cost-savings defense to the brokerage clause are equally poorly defined. The two circuits that recognize this defense disagree upon the basic issues of what cost-savings shall be acknowledged ${ }^{87}$ and the method of proving these savings. ${ }^{88}$ Consequently, the scope of the brokerage clause and the nature of defenses to its imposition remain in a state of flux, unclarified by any significant litigation during the past few years. Given this absence of consistent development, the potential defendant to a 2(c) accusation can have little confidence in the successful utilization of these defenses.

\section{Sections 2(d) and 2(e)-Promotional FACILITIES AND ALLOWANCES}

The proscriptions of sections 2(d) and 2(e) were enacted, as was section $2(\mathrm{c}){ }^{89}$ to prevent indirect price discrimination ${ }^{90}$ by precluding suppliers from granting promotional benefits in connection with sales to favored customers, while contemporaneously withholding proportionate concessions from the customers' competitors. ${ }^{91}$ A prima facie violation of section 2(d) is established if it is shown that a supplier discriminated by compensating only selected customers for

\footnotetext{
"see notes 39,41 \& 45 supra.

${ }^{25}$ See note 50 supra and accompanying text.

"See notes 28-31, 61-68 supra and accompanying text.

"See notes 28-31, 61-68 supra and accompanying text.

"See note 5 supra.

${ }^{90}$ See notes 7 \& 8 supra.

"Although "seetions 2(d) and 2(e)'s literal text is susceptible to extension beyond the area of promotional arrangements related to the customer's resale of the supplier's product, decisions of the Federal Trade Commission and courts have repudiated such strained applications and confined these provisions to their legislatively contemplated promise." RowE at 380. See, e.g., Skinner v. United States Steel Corp., 233 F.2d 762 (5th Cir. 1956) (discriminatory credit arrangement held not actionable under section 2(e) ); American Can Co. v. Russellville Canning Co., 191 F.2d 38, 56 (8th Cir. 1951) (freight and delivery arrangements ruled price discriminations and not violative, as furnishings, of section 2(e) ).

Where a discriminatory promotional allowance exists, however, the question remains whether the FTC has a choice to bring the action under either the price discrimination provisions of section 2(a) or seetion 2(d). If payments are not given for, or in contemplation of, promotional services, the Commission considers them to be without the scope of $\S 2$ (d) and subject to
} 
customer-performed promotion.92 Section $2(\mathrm{e})$ is violated if the supplier similarly discriminates in performing promotional services for selected buyers. ${ }^{93}$ Although variations in the wording of the texts of sections 2(d) and 2(e) have been the source of substantial confusion as to their interrelationship, ${ }^{94}$ the sections are now generally recognized as complimentary ${ }^{95}$ and, thus, avoidable by the same defenses. ${ }^{96}$

While the qualifying language of section 2(c) has been subject to conflicting interpretations, it is clear that sections 2(d) and 2(e) do not promulgate absolute proscriptions. Rather, the text of both sections indicates that their effect may be negated if the respondent-supplier shows that there was no discrimination between competing customers

consideration only under § 2(a). See Yakima Fruit \& Cold Storage Co., 59 F.T.C. 693 (1960); Rowe at 386. However, this subjective standard, requiring consideration of the intent of the supplier at the time the allowance is made, seems impractical since it necessitates a difficult and probably inaccurate inquiry into the "mental processes" of an individual or a corporation. See Note, 41 Notre Dame Law. 382, 386 (1966).

${ }^{22}$ The cnforcement agency must show merely that one customer received promotional aid while it was contemporaneously withheld from others in order to shift the burden of justifying the discrimination to the respondent. R.H. Macy \& Co. v. FTC, 326 F.2d 445 (2d Cir. 1964); Vanity Fair Paper Mills, Inc. v. FTC, 311 F.2d 480, 486 (2d Cir. 1962). The Commission is not required to show, as in section 2(a) litigation, that such a "discrimination" had any injurious effect upon competition. FTC v. Simplicity Pattern Co., 360 U.S. 55, 65 (1959). See generally Note, 68 Yale L.J. 808 (1959); 28 Geo. Wash. L. Rev. 671 (1960); 42 MarQ. L. Rev. 262 (1958).

${ }^{93}$ Sce note 92 supra.

${ }^{24}$ See Fisher, Sections 2(d) and 2(e) of the Robinson-Patman Act: Babel Revisited, 11 VAND. L. REv. 453, 467 (1958). However, the differing terms of sections 2(d) and 2(e), "customer" and "available" in the former as compared to "purchaser" and "accorded" in the lattcr, are considered interchangeable. Also, the phrases "competing in the distribution of such products and commodities" and "engaged in commerce," of 2(d) are read into section 2(e). See id. at 47681; Comment, 29 U. CHI. L. REV. at 165. Ultimately, "[m]inor discrepancies in these twin provisions were ironed out by courts ready to resolve the two subsections into a harmonious whole." ATT'y GeN. REP. 189. See, e.g., FTC v. Simplicity Pattern Co., 360 U.S. 55, 62 (1959); American News Co. v. FTC, 300 F.2d 104, 109 (2d Cir. 1962); Elizabeth Arden Sales Corp. v. Gus Blass Co., 150 F.2d 988, $992-93$ (8th Cir.), cert. denied, 326 U.S. 773 (1945); K.S. Corp. v. Chemstrand Corp., 198 F. Supp. 310,312 (S.D.N.Y. 1961).

os "lt secms clear. . . that sections 2(d) and 2(e) are companion sections and that distinctions between them should not be drawn merely because of the differences in terminology employed in each section. These sections are companion sections to the extent that they have the same purpose and seek to eliminate the same evil ...." State Wholesale Grocers v. Great Atl. \& Pac. Tea Co., 154 F. Supp. 471,474 (N.D. 111. 1957), modified on other grounds, 258 F.2d 831 (7th Cir. 1958), cert. denied, 358 U.S. 947 (1959); see Note, 41 Notre Dame LAw. 382, 383 (1966); Comment, 29 U. CHI. L. REv. at 165.

* See notes 94-95 supra. See generally Kintner, Merchandising Allowances and Services: Sections 2(d) and 2(e) of the Robinson-Patman Act, 41 Notre DAME LAW. 364, 365-67 (1966). 
because promotional benefits were "available" to all on "proportionally equal terms." " In order to establish "availability," a respondent-supplier usually must demonstrate that promotional aids were actually offered to all competing customers. ${ }^{99}$ Thus, a prudent supplier uses a method of offering promotional aid which provides a verifiable record, such as written copies of offers mailed. ${ }^{100}$ Further, a supplier's demonstration that his promotional plan provided for a universal offer apparently fails to demonstrate sufficient "availability" if such offers are not, in fact, made in accordancc with the plan. Thus, the initial supplier is required to police the administration of the promotional scheme in order to ensure that the proper distribution of benefits is fully implemcnted. ${ }^{101}$ Concomitantly, to establish "proportional equality," an alleged

\footnotetext{
${ }^{97}$ See notes 8 \& 9 supra. See generally Rowe at 399-414; Kintner, note 96 supra, at 365-67.

${ }^{93}$ See notes 8 \& 9 supra. Although sections 2(d) and 2(e) were enacted to curtail the bargaining power of powerful buyers, see notes $7 \& 8$ supra, the sections are directed at controlling the conduct of the supplier by forbidding him to yield to any unfair demands by powerful buyers. Seetion $2(f)$ is directed toward the purchaser: "[l]t shall be unlawful for any person engaged in commerce, in the course of such commerce, knowingly to induce or receive a discrimination in price which is prohihited by this seetion." Robinson-Patman Act $\S 2,15$ U.S.C. $§ 13(f)$ (1964). See generally Frey, The Evidentiary Burden on Affirmative Defenses Under Section 2(f) of the Robinson-Patman Act: Automatic Canteen Revisited, 36 GEO. WASH. L. REv. 347 (1967) (discussion of defenses available to a respondent-buyer under seetion 2(f)).

59 The Commission has recognized that secret promotional concessions are not "available." See, e.g., Celanese Corp. of America, 46 F.T.C. 1170, 1173-74 (1950); N. Erlanger, Blumgart \& Co., 46 F.T.C. 1139, 1142 (1950); National Modes, lnc., 46 F.T.C. 404, 419, 436 (1950). Both the Commission and the courts require that suppliers offer aid to all purchasers. See, e.g., Vanity Fair Paper Mills, Inc. v. FTC, 311 F.2d 480 (2d Cir. 1962); Henry Rosenfeld, Inc., 52 F.T.C. 1535, 1548 (1956); Kay Windsor Frocks, Inc., 5 I F.T.C. 89, 94-95 (1954). The Commission has, thus, advised that "[t]he seller should take some action to inform all his customers who compete with any participating customer that the promotion is available." Federal Trade Commission 1967 Guides for Advertising Allowances and Other Merchandising Payments and Services, 16 C.F.R. $\$ 240.6(\mathrm{~b})$ [hereinafter cited as FTC Guides]. Further, the Commission suggests that "[t]he seller and customer should have a clear understanding about the exact terms of the offer and the conditions upon which payments will be made for services and facilities furnished." Id. at $\$ 240.6$ (d).

${ }_{100}$ The Commission acknowledges that a supplier may undertake the offer "by any means he chooses, including letter, telegram, notice on invoices, salesman, brokers, etc." It is reeommended that "if a seller wants to be able to show later that he did make an offer to a certain customer, he is in a better position to do so if he made it in writing." FTC Guides $\$ 240.8$.

${ }^{101}$ A respondent cannot establish "availahility" by proving merely "that respondent's sales representatives had been 'advised' of its policies with respect to speeial promotional allowances and instructed to inform respondent's customers thereof ...." Vanity Fair Paper Mills, lnc. v. FTC, 31 I F.2d 480, 485 (2d Cir. 1962). Rather, to meet the availahility standard, such a respondent must show that the sales rcpresentatives had carried out such instructions. Id.
} 
violator of section 2(d) or 2(e) must prove that his promotional subsidies were ultimately allotted on a measurable objective basis. ${ }^{102}$ Although acknowledging that no single method is required, ${ }^{103}$ the FTC seems to prefer plans which apportion aid on the basis of the customer's purchase volume. ${ }^{104}$ Finally, since promotional offers are not "available" if specifically tailored for ${ }^{105}$ or within the economic limitations of ${ }^{106}$ only a few selected buyers, a promoter-supplier may be required to show that his promotional program provided viable alternative forms of media participation designed to fit his customers' adverse business and financial needs. ${ }^{107}$

${ }^{102}$ See, e.g., Chicago Spring Prod. Co. v. U.S. Steel Corp., 254 F. Supp. 83 (N.D. Ill.), affd, 371 F.2d 428 (7th Cir. 1966); Day's Tailor-D Clothing, Inc., 55 F.T.C. 1584 (1959); Black Mrg. Co., 54 F.T.C. 1196 (1958); Revlon Prods. Corp., 53 F.T.C. 127 (1956); Elgin Watch Co., 48 F.T.C. 990, 997 (1952). See generally RowE, at 404-09.

${ }^{103}$ The Commission has stated that "[n]o single way to proportionalize is prescribed by law. Any method that treats competing customers on proportionally cqual terms may be used." FTC Guides $\S 240.7$. Generally, "any properly measurable basis is acceptable if it is not artificially tailored into proportionally equal terms by fitting it into some imaginery basis or standard that never, in fact, existed." Patman at 135.

${ }^{104}$ The Commission has stated that proportion can "generally . . . best be done by basing the payments made or the services furnished on the dollar volume or the quantity of goods purchased during a specified time." FTC Guides $\S 240.7$. Three programs have been suggested by which a respondent may conform to the requirements of $\S \S 2$ (d) and 2(e): (l) payment of a dollar allowance per unit of promotional service rendered by each buyer, up to a uniform maximum percentage of his dollar volume; (2) a simplified plan, granting each buyer a set dollar allowance per unit of merchandise bought, on condition that he perform a specified minimum quantum of promotional services; and (3) the seller's direct furnishing of promotional services to the buyer, worth a uniform percentage of each buyer's volume. ATT'Y GEN. REP. at 189; see e.g., Colgate-Palmolive-Peet Co., 50 F.T.C. 525 (1953); Proctor \& Gamble Distrib. Co., 50 F.T.C. 513 (1953); Lever Bros. Co., 50 F.T.C. 494 (1953).

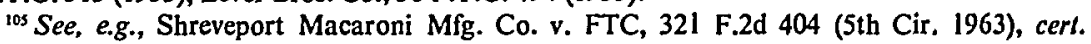
denied, 375 U.S. 971 (1964) (special allowances to chain stores); Vanity Fair Paper Mills, Inc. v. FTC, 311 F.2d 480 (2d Cir. 1962) (participation in a chain store's anniversary sale); Hartley \& Parker, Inc. v. Florida Beverage Corp., 307 F.2d 916 (5th Cir. 1962) (serviees to one distributor); Elizabeth Arden, Inc., 39 F.T.C. 288 (1944), aff d, 156 F.2d 132 (2d Cir. 1946), cert. denied, 331 U.S. 806 (I947). See Kintner, note 96 supra, at 366.

${ }^{106}$ Simply stated, "[a]n offer to make a service available to one the economic status of whose business renders him unable to accept the offer, is tantamount to no offer at all." State Wholesale Grocers v. Great Atl. \& Pac. Tea Co., 258 F.2d 831, 839 (7th Cir. 1958), cert. denied, 358 U.S. 947 (1959); accord, Shreveport Macaroni Co. v. FTC, 321 F.2d 404 (5th Cir. 1963), cert. denied, 375 U.S. 971 (1964) (minimum eligibility of 9000 cases per year); Atlanta Prod. Corp., No. 8513 (F.T.C., Dec. 13, 1963) (minimum of $\$ 1500$ worth of purchases in six month period); Lean \& Fink Prod. Corp., No. 8506 (F.T.C., July 27, 1964) (promotion only available if buyer purchases full line of seller's goods); see RowE at 400; Kintner, note 96, supra, at 366-67.

107 "The plan must allow all types of competing customers to participate . . . . This may require offering all customers more than one way to participate in the plan. The seller cannot expressly, or by the way the plan operates, eliminate some competitive customers. Where the 
By demanding that participation in the promotional plan be economically feasible for all customers, the Commission and the courts have drastically limited the supplier's discretion both as to determining which customers will receive aid and as to choosing the type of promotional media subsidized. These restrictions have been challenged as unreasonable since they may reduce the effectiveness of the supplier's entire promotional plan by mandating patronage of relatively ineffective promotional methods. ${ }^{108}$ Additionally, a supplier might be forced to associate his product with a customer whose public image is unsatisfactory. ${ }^{109}$ Although the possibility of hardship to the supplier is undeniable, it would seem to be an unavoidable incident in attaining the purposes of sections 2(d) and 2(e), since without the stringent requirement that participation in promotional offers be possible for all buyers, a seller would be free to confer substantial competitive advantage upon favored customers. ${ }^{110}$

Despite a supplier's inability to establish that promotional aid was made "available" to all customers on "proportionally equal" terms, liability under sections 2(d) and 2(e) may still be avoided by reliance upon the language of the section which proscribes discrimination in

seller has alternative promotional plans, his customers must be given the opportunity to choose among the plans.

"Example 1.S offers a plan for cooperative advertising on radio, television or in a newspaper. Some of his customers who compete with those who receive the allowance are too small to use the offer. He must offer them some usable and proportional alternative, such as advertising in a neighborhood paper, handbills, etc. ..." FTC Guides $§ 240.9$; see, e.g., Colgate-PalmolivePeet Co., 50 F.T.C. 525 (1953) (different amounts of aid granted for newspaper, radio, handbill advertisements and indoor displays); Proctor \& Gamble Distrib. Co., 50 F.T.C. 513 (1953) (same); Lever Bros. Co., 50 F.T.C. 495 (1953) (same).

${ }^{108}$ See Oppenheim, note 74 supra, at 1207 n.179. A Commissioner of the Federal Trade Commission has attacked sections 2(d) and 2(e) as undue restrictions upon the free enterprise system based upon the economically irrational assumption that all promotional allowances are disguised price rebates. Elman, note 84 supra, at 26-27. Stressing the significant interference with supplier choice of promotional recipients and methods, Commissioner Elman contends that the ultimate question would be "whether so serious an interference with a supplier's discretion in allocating his advertising resources is justified, in the absence of any inquiry whatsoever as to effect on competition." Id. at 27. This argument has likely been one of the factors lcading to a perceptible recent ad hoc trend against per se application of the promotional sections. See notes 76-81, 106-09 infra and accompanying text. The argument is actually not a recent development, however, as Oppenheim early recognized that such interference was not required and suggested that the Act be rewritten to proscribe only those allowances that lessen competition. See Oppenheim, note 74 supra, at 1207.

${ }^{109}$ See Elman, note 84 supra, at 26.

110 Elman admits that "[i]f a [supplier] may budget his cooperative advertising program so as to select those purchasers with the greatest prestige, the result may be to confer substantial competitive advantages on large buyers." See Elman, note 84 supra, at 27 . Such action is 
promotional assistance only between competing customers. ${ }^{111}$ Thus, the prohibitions of 2(d) and 2(e) are inapplicable if a respondentsupplier proves that the customers from whom promotional aid was withheld did not compete in the resale of their purchases with the subsidized customer because the goods sold to each customer group were not of "like grade and quality." 112 ln determining the meaning of this term for purposes of Robinson-Patman Act litigation, intangible characteristics which may influence the consumer's demand for the product, such as brand names, apparently may not be considered in deciding whether goods purchased by different customers are sufficiently dissimilar. ${ }^{113}$ Rather, relying upon the legislative history of the Act $^{114}$ and noting the Commission's preference for a physical

diametrically opposed to the purpose of $\S \S 2$ (d) and 2(e), recently defined by the Supreme Court as protection of the small buyer. See note 153 infra and accompanying text.

'I' The text of $\S 2(\mathrm{~d})$ indicates that only those "customers competing in the distribution" of the supplier's goods are entitled to proportionally equal treatment. See note 8 supra. This "competing" requirement is read into § 2(e). See note 94 supra. See generally Rowe 394-99; Kintner, note 96 supra, at 367-69.

${ }^{112}$ The sections 2(d) and 2(e) requirement of competing purehasers, see notes 8 \& supra, has been interpreted to mean purchasers of products and commodities "of like grade and quality," as in section 2(a). See, e.g., Atalanta Trading Corp. v. FTC, 258 F.2d 365, 369, 372 (2d Cir. 1958); Matter of Golf Ball Mfgrs. Ass'n, 26 F.T.C. 824, 851 (1938). See generally Comment, Like Grade and Quality: Emergence of the Commercial Standard, 26 Oно ST. L.J. 294 (1965) [hereinafter cited as Comment, 26 Oнı St. L.J.]; Note, 49 MinN. L. Rev. 1176 (1965).

${ }^{113}$ See FTC v. Borden Co., 383 U.S. 637 (1966). In Borden, the Supreme Court demonstrated the ir relevance of brand appeal by rejecting the Court of Appeals' ruling, 339 F.2d 133 (2d Cir. 1964), that a manufacturer's private brand and premium brand of milk were not goods of "like grade and quality," although chemically identical, because of the consumers' preference for the premium brand. See generally Cox, The Supreme Court 1965 Term, 80 HARv. L. Rev. 91, 23640 (1966); 19 VANDERBILT L. REV. 919 (1966).

"114 In FTC v. Borden Co., note 113 supra, the Court noted that during the Robinson-Patman hearings an amendment was proposed to make the legislation applicable only to sales of commodities of "like grade, quality and brand." 383 U.S. at 641 . However, this amendment was rejected upon the argument that the modification would destroy the efficacy of the bill by allowing suppliers to discriminate easily by selling different brands to favored eustomers. $\boldsymbol{l d}$. at 641-42 n.4. Although this objection was reasonable since the proposed amendment would have allowed a supplier to differentiate products through the use of commercially insignificant brands, it may be contended that rejection of the proposed "brand" amendment was ineorreetly interpreted by the Court to exclude any consideration of commcrcially significant brand differences under the present "like grade and quality" standard. See Comment, 26 OHI ST. L.J. at 316-18; notes 121-23 infra and accompanying text.

Moreover, the Court considered as indicative of Congressional intent that brands not be considered in deciding "like grade and quality," 383 U.S. at 643, the statements by Representative Patman, sponsor of the legislation, to the effect that brand would not suffice to differentiate products that are of the same physieal quality. 80 CONG. REC. 8115 (1936). 
comparison test, ${ }^{115}$ the Supreme Court has required a respondent to show that goods are not "physically and chemically alike" 116 before the Act may be avoided. ${ }^{117}$ Consequently, to rebut a prima facie violation of section $2(\mathrm{~d})$ or $2(\mathrm{e})$, a respondent supplier must establish that the goods purchased by his customers were not of "like grade and quality" by showing that they were of diverse design, size, or composition. ${ }^{118}$

This physical comparison standard for "like grade and quality" may be criticized as unrealistic since it fails to recognize that the final

is See FTC v. Borden Co., 383 U.S. at 640, citing Whitaker Cable Corp., 51 F.T.C. 958 (1955); Page Dairy Co., 50 F.T.C. 395 (1953); United States Rubber Co., 46 F.T.C. 998 (1950); United States Rubber Co., 28 F.T.C. 1489 (1938); Hansen Innoculator Co., 26 F.T.C. 303 (1938); Goodyear Tire \& Rubber Co., 22 F.T.C. 232 (1936).

"16 See FTC v. Borden Co., 383 U.S. 637 (1966); note 115 supra. In Borden, the Court failed to explore the related and salient issue concerning the degree of physical or chemical variation which is necessary to establish product distinction. Unfortunately, the Commission has been inconsistent in deciding this question. In several cases, the FTC has indicated that any physical diffcrence would differentiate products. See, e.g., Atalanta Trading Corp., 53 F.T.C. 565 (1956) (violation of $\S 2$ (d) found by subsidizing specially processed and packaged Canadian bacon but not ham), rev'd on other grounds, 258 F.2d 365 (2d Cir. 1958).

However, more recent decisions indicate that only physical differences which affect a consumer's preference will suffice to distinguish products. See, e.g., Quaker Oats Co., [19631965 Transfer Binder] TRADE REG. ReP. I 16948, at 22,213 (FTC 1964) (different contents of oat flour held not to distinguish); General Foods Corp., 52 F.T.C. 798 (1956) (different coffee beans of like grade and quality). See generally Note, 49 MinN. L. Rev. 1176, 1182-87 (1965). Several courts bave also applied this "commercially significant pbysical difference" test. See Atalanta Trading Corp. v. FTC, 258 F.2d 365 (2d Cir. 1958); Central lce Cream Co. v. Golden Rod lce Cream Co., 184 F. Supp. 312 (N.D. 11l. 1960), aff $d$, 287 F.2d 265 (7th Cir. 1961); Bruce's Juices, Inc. v. American Can Co., 87 F. Supp. 985 (S.D. Fla. 1949), aff d, 187 F.2d 919 (5th Cir.), modified. 190 F.2d 73 (5th Cir.), cert. denied, 342 U.S. 875 (1951). The status of this more sophisticated approach to product differentiation is uncertain, however, in light of the Supreme Court's failure to expound upon the precise constituents of the physieal and chemical similarity test to which it adhered in Borden.

"17 The FTC's emphasis upon a physical test in determining "like grade and quality" under $\S \S$ 2(a), 2(d) and 2(e), relied upon by the Borden majority, has becn criticized as inconsistent with the position assumed by the Commission when the "meeting competition" defense of $\S 2$ (b) is advocated. See note 173 infra. In several cases, the Commission has disallowed the § 2(b) defense by ruling that an intense public preference for a certain brand which causes the lowering of that brand's prices to the price level of a less desired, non-premium brand is not "mecting" but "beating," sce note 177 infra and accompanying text, the latter brand's competition. See Callaway Mills Co., [1963-1965 Transfer Binder] TRADE REG. ReP. I 16,800, at 21,755 (FTC 1964), noted in 39 N.Y.U.L. Rev. 1104 (1964); Standard Oil Co., 49 F.T.C. 923,952 (1953); Minneapolis-Honeywell Regulator Co., 44 F.T.C. 351, 396 (1948), rev'd on other grounds, 191 F.2d 786 (7th Cir. 1951). Thus, the Commission apparently applied a standard that does not recognize consumer brand preference in certain cases while, without explanation, it relies upon brand differenee in § 2(b) litigation. See generally Comment, 26 Oнго ST. L.J. at 308-11.

"See note 116 supra. 
decision as to what are "like" products is made by the consumer and that this decision is not made upon the basis of chemical analysis but upon a general economic comparison of the product." 19 Brand names, irrelevant under the Supreme Court's test, may significantly influence ultimate consumer choice by indicating the greater dependability or quality of a product. ${ }^{120}$ Arguably, if such intangibles are not considered, the function of the "like grade and quality" requirement in limiting application of Robinson-Patman to competitive transactions may be perverted under the narrow physical comparison test since it enables suppliers to elude the Act by merely incorporating slight tangible variations in their products. ${ }^{121}$ This inherent deficiency in the physical similarities standard has caused several courts to advocate a "market test" under which "like grade and quality" is determined by emphasis upon the cross-elasticity of consumer demand for the specified products-whether the consumer considered the goods interchangeable at the same price. ${ }^{122}$ Under this standard, due consideration is accorded to both physical and intangible characteristics influencing consumer demand for the product in

\footnotetext{
"119 See FTC v. Borden Co., 383 U.S. 637, 648 (1965) (dissent); Comment, 26 OHIO ST. L.J. at 296.
}

${ }^{120}$ It has been argued that "[aln important ingredient of the premium brand inheres in the consumer's belief, measured by past satisfaction and the market reputation established by la brand] for its products, that tomorrow's can will contain the same premium product as that purchased today." FTC v. Borden Co., 383 U.S. 637, 651 (Stewart, J., dissenting). In Borden, the dissenters noted that there was a basis for this attributed quality of the premium product since the supplier took special precautions with his premium product to see that "flawed" products did not reach the consumer. Id.

${ }^{121}$ Although adoption of the "physical-comparison" test may allow suppliers to avoid the statute by incorporating slight tangible variations in their products, and thereby distinguishing them as not of "like grade and quality," FTC v. Borden Co., 383 U.S. 637, 657 (1966) (Stewart, J., dissenting), this danger may be mitigated by the developing requirement in FTC litigation that goods differ in a significant physical characteristic before they may be distinguished. The status of this standard is somewhat unclear, however, after Borden. See note 116 supra.

122 In Atalanta Trading Corp. v. FTC, 258 F.2d 365 (2d Cir. 1958), the Second Circuit, although initially rejecting a "cross-elasticity" standard, indicatcd approval of a "substitutability" test under which goods sought by the same consumers for the same purpose and which were competitive "price-wise" would constitute products of "like grade and quality." Id. at 371 n.5. See Borden Co. v. FTC, 339 F.2d 133 (5th Cir. 1964), rev'd, 383 U.S. 637 (1966); cf. Universal-Rundle Corp., [1963-1965 Transfer Binder] Trade Reg. Rep. If 16,948, at 22,002 (FTC 1964).

Although variously titled, equivalent "market" standards recognizing that consumer demand for a given product is influenced both by the product's tangible and intangible characteristics have been long advocated. See Rowe 74-76; ATr'y GEN. ReP. at 158; Comment, 26 OHIO ST. L.J. at 294. Moreover, it has been suggested that the scope of "like grade and quality" be expanded to any products, regardless of their physical or promotional characteristics, that affect 
issue. ${ }^{123}$ In any event, it seems likely that a supplier's attempt to justify selective promotional assistance on the ground that no discrimination existed between "competing" customers may be perceptibly strengthened by differentiating the products sold, both on the basis of physical differences and under the compelling thcoretical rationale of the "market test" analysis. ${ }^{24}$

The competitive transaction limitation of sections 2(d) and 2(e) may also be used to avoid application of sections 2(d) and 2(e) by proving that there were no "competing" customers at the time of, or for a reasonable period after, the offer of promotional aid was made to the subsidized buyer. ${ }^{125}$ The purpose of these sections in insuring that all customers of a supplier be treated fairly and equally has been considered to require only that the supplier make promotional offers

through price change or promotion one another's competitive position. See Note, 49 MiNN. L. REV. 1176, 1188-96 (1965).

123 Neither the "physical comparison" test nor the "market" test is acceptable in its "pure" form. If only the physical characteristics are considered, tbe scope of $\$ \S 2(a), 2(d)$, and 2(e) may be too narrow to effectuate the Robinson-Patman Act's primary purpose of ensuring that customers of diverse size will be accorded fair treatment in similar sales transactions since relatively superficial physical variation may justify discriminatory assistance. See note 116 supra. Conversely, a pure market standard that determined "like grade and quality" only by cross-elasticity of demand for products is too broad because this standard would encompass all products that perform the same general function. See Comment, 26 OHIO ST. L.J. at 322. Thus, a hybrid standard has been suggested that would first determine "like quality" by considering the significant physical characteristics of a product. If the products could not be distinguished by this examination of physical characteristics, the intangible characteristics would be considered to determine "like grade." Only if both the "like quality" and "like grade" considerations were satisfied would the seetions be applied. Id. at 322-25. This hybrid, however, has yet to be tested before a court or the Commission.

124 See notes 119-22 supra and accompanying text.

${ }^{125}$ See Atalanta Trading Corp. v. FTC, 258 F.2d 365 (2d Cir. 1958). In Atalanta, a large food distributor was charged with a violation of $\S 2$ (d) when, after granting promotional allowances to its only purchaser in a market area, it refused to grant the same allowances to buyers who moved into the area five months later. Also, the respondent had granted special Christmas allowances to the same purchaser upon a product that eight months earlier had been sold unpromoted to other purcbasers in the market area. Reversing the Commission's cease and desist order against the distributor on the ground that the transactions were not reasonably simultaneous, the Court of Appeals for the Second Circuit concluded that section 2(d) permitted sales with promotional allowances subsequent to sales without allowances since the converse rule would stifle competition by not allowing a supplier to meet competition. Id. at 371 . See notes 173-90 infra and accompanying text. Similarly, the court held that under $\S 2$ (d) a supplier was not required to continue promotional offers after a "certain period of time," despite acceptance by less than all suppliers, since "the terms of an initial sale . . . would freeze the supplier into an immutable position." 258 F.2d at 372 . Thus, both the court and the Commission recognize that, in a $\S 2$ (d) or, presumably, $\S 2$ (e) violation "the time interval [betwecn sales] is a determining factor." Id.; see Tri-Valley Packing Ass'n v. FTC, 329 F.2d 694 (9th Cir. 1964); Kay Windsor 
available for reasonably simultaneous transactions. ${ }^{126}$ This temporal limitation upon the proscriptions of sections $2(\mathrm{~d})$ and 2(e) seems to evidence a tacit recognition that promotional campaigns fail to effect permanently consumer preference among the supplier's vendees since promotional messages are commonly either disregarded or soon forgotten. ${ }^{127}$ Moreover, if these sections were not so limited, suppliers would be deterred from making any offers of promotional assistance by the immense financial burden of being permanently bound to such offers. ${ }^{128}$ Unfortunately, the decisions have not been instructive as to the criteria considered in determining when transactions are "reasonably simultaneous." 29 Nevertheless, it may be suggested that the market characteristics of the goods purchased by the supplier's customers, ${ }^{130}$ including whether they support a seasonal market or are annually obsolete, and the nature of the promotional aid both as to

Frocks, Inc., 51 F.T.C. 89 (1954); cf. Valley Plymouth v. Studebaker-Packard Corp., 219 F. Supp. 608 (S.D. Cal. 1963), noted in 5 B.C. IND. \& Com. L. Rev. 479 (1964). See generally ROWE 48-51, 391-92; ATT'Y GEN. REP. at 178.

126 "[T] $]$ he supplier's obligations to ensure 'proportional equality" extend only to those who buy his promoted products at approximately the same time." Rowe at 391.

${ }_{127}$ It may be argued that the failure to find a \$2(d) violation in Atalanta Trading Corp. v. FTC, 258 F.2d 365 (2d Cir. 1958), note 125 supra, was based upon the conclusion that competitive injury was impossible since the passage of time had negated the cffect of any discrimination between customers. In Atalanta, the court avoided a direct confrontation with the rule that proof of competitive injury is not required for a $\S 2$ (d) or $\S 2$ (e) violation promulgated in Simplicity Trading Co. v. FTC, 258 F.2d 673 (D.C. Cir. 1958), modified, 360 U.S. 55 (1959), by reasoning that there was no discrimination among purchasers by Atalanta since none of the non-subsidized purchasers bought their goods within a reasonable time of the subsidized transaction. See Atalanta Trading Corp. v. FTC, 258 F.2d 365, 372 (2d Cir. 1958). The court concluded that "[a]ssuming the validity of dispensing with proof of actual competitive injury, to hold that Section 2(d) has been violated in the face of a record revealing that the promotional allowances could not possibly have had any discriminatory effects would establish an inflexible rule at odds with the basic concept of free competition. The two trivial sales isolated in time by at least five months from the substantial sales on which the allowances were given do not violate either the letter or the spirit of Section 2(d)." Id. (emphasis added).

${ }^{122}$ Cf. Atalanta Trading Corp. v. FTC, 258 F.2d 365, 372 (2d Cir. 1958); note 125 supra.

${ }^{129}$ The courts have merely stated certain time periods as demarcating the limits of reasonable simultaneity without indicating the basis upon which the particular duration utilized was selected. See Tri-Valley Packing Ass'n v. FTC, 329 F.2d 694, 709 (9th Cir. 1964) (one year); Atalanta Trading Corp. v. FTC, 258 F.2d 365, 371 (2d Cir. 1958) (eight months).

${ }^{130}$ In Atalanta Trading Corp. v. FTC, 258 F.2d 365 (2d Cir. 1958), see note 125 supra, a significant factor in determining simultaneity apparently seems to have been the perishable nature of the pork products being promoted. See 258 F.2d at 372. Also, the systematic introduction of a new product resulting in the obsolescence of the old model, as in the automobile industry, may limit the time of reasonably simultaneous transactions to, at most, the period of the current model. See Valley Plymouth v. Studebaker-Packard Corp., 219 F. Supp. 608 (S.D. Cal. 1963); Rowe 50. 
the amount and the type of promotion subsidized, ${ }^{131}$ will be studied in deciding whether separate sales transactions were within the temporal purview of section 2(d) or 2(e).

Although not yet singularly advocated as a defense to section 2(d) or 2(e), a third approach apparently available to a supplier is to establish that his customers are not "competing" for the same group of customers. ${ }^{132}$ If the fundamental requirement is to demonstrate a practical impossibility of competitive disadvantage resulting from discriminatory promotional assistance among buyers from a common vendor, it seems arguable that a supplier may permissibly differentiate in promotional service to customers that are so geographically distant from each other that they are not viable alternative sources of purchase for the same vendees. ${ }^{133}$ Thus, a respondent might endeavor to establish that his customers are not actually entitled to equal promotional treatment by presenting evidence concerning the mileage, ${ }^{134}$ natural boundaries ${ }^{135}$ and/or artificial boundaries ${ }^{136}$ that

\footnotetext{
13' The seasonal nature of the promotion subsidized, Christmas wrappings and recipes and picnics for July Fourth, seems clearly to have affected the court's determination regarding the period between reasonably simultaneous transactions in Atalanta Trading Corp. v. FTC, 258 F.2d 365, 371 (2d Cir. 1958). Similarly, the small amount of aid rendered compared to the amount of purchases made by the recipient was especially significant to the court. Id. at 367 .

132 "The seller is required to provide in his plan only for those customers who compete in the distribution of the promoted product with the customer who is participating in the promotion. Therefore, the seller can limit the area of his promotion to that in which partieipating customers sell.

$\ldots$

"Example 2. Manufacturer A distributes his products nationally. He may lawfully engage in a special promotional eampaign in the New England states without making the same program available to customers in the remainder of the country who do not compete with New England customers." FTC Guides § 240.12. See also Kintner, note 96 supra, at 365-66. Although no § 2(d) or 2(e) litigation has been dismissed on this ground, both the Commission and the courts have indicated the necessity for competition within the geographie area by analyzing cases to determine its presence. See, e.g., Flotill Prods., Inc. v. FTC, 358 F.2d 224, 232 (9th Cir. 1966); Joseph A. Kaplan \& Sons, Inc. v. FTC, 1965 Trade Cas. I 71,444 (D.C. Cir. 1965), aff g 57 F.T.C. 1537 (1960), modifying 56 F.T.C. 1689 (1960).

${ }^{13}$ See note 132 supra. However, the supplier would not be able to avoid the proscriptions of $\S$ 2(d) or 2(e) by showing merely that he had no reason to know of his customers' competition. An objeetive standard is imposed under these seetions by which liability accrues if there is actual competition, regardless of whether the supplier had reason to know of it. See Flotill Prods., Inc., [1963-1965 Transfer Binder] Trade Reg. Rep. I 16,970, at 22,032 (1964), aff d, 358 F.2d 224, 232 (9th Cir. 1966).

14 Cf. Flotill Prods., Inc. v. FTC, 358 F.2d 224, 232 (9th Cir. 1966).

iss See National Lead Co. v. FTC, 227 F.2d 825, 836 (7th Cir. 1955), rev'd on other grounds, 352 U.S. 419 (1957); Forster Mfg. Co., 56 F.T.C. 1633 (1959).

${ }^{136}$ See Purex Corp., 51 F.T.C. 100, 174-77 (1954). For a discussion of area discrimination
} 
separate his customers and discourage their cross-selling. Furthermore, testimony of the customers' vendees regarding their purchasing habits may be persuasive in establishing that customers are not "competing." 137

A final method of demonstrating customer distinction sufficient to permit discriminatory promotional aid is to prove that the supplier's subsidized vendee was not "competing" with the unfavored customers because they performed differcnt functional roles. ${ }^{138}$ Functional disparity is apparently determined by considering whether the customers are in actual commercial rivalry regarding resale of their purchases to the same type of buyer. ${ }^{139}$ For example, a supplier's customer vending only to retailers would be a wholesaler and would not, therefore, be considered to be in competition with a retailing purchaser who resells only to the consuming public. Thus, such retailers and wholesalers generally have not been entitled, under section 2(d) or 2(e), to proportionally equal promotional treatment by their common supplier. ${ }^{140}$ However, the Supreme Court, in Federal Trade Commission v. Fred Meyer, $I n c,{ }^{141}$ has recently cast doubt upon both the validity and practical value of this "functional role" defense.

In Fred Meyer, Inc., thc Supreme Court ruled that a supplier granting promotional aid to direct dealing retailers must, in order to

under $\S 2$ (a) see Thumann, Territorial Discrimination, Robinson-Patman, and a Rule of Reasonable Probability, 8 U.C.L.A.L. REV. 363 (1961).

${ }^{137}$ See Flotill Prods., 1nc. v. FTC, 358 F.2d 224, 232 (9th Cir. 1966).

${ }^{133}$ See, e.g., Crest Auto Supplies, Inc. v. Ero Mfg. Co., 360 F.2d 896 (7th Cir. 1967); Fred Meyer, lnc. v. FTC, 359 F.2d 351 (9th Cir. 1966), rev'd on other grounds, 390 U.S. 341 (1968); Tri-Valley Packing Ass'n v. FTC, 329 F.2d 694, 710 (9th Cir. 1964); Liggett \& Myers Tobacco Co., 56 F.T.C. 221 (1959); Elizabeth Arden, Inc., 39 F.T.C. 288 (1944), affd, 156 F.2d 132 (2d Cir. 1946), cert. denied, 331 U.S. 806 (1947). But see Krug v. International Tel. \& Tel. Corp., 142 F. Supp. 230 (D.N.J. 1956). See generally Rowe 395-98; Kintner, note 96 supra, at 368 .

${ }^{139}$ See Millistein, Section 2(d) and 2(e) of the Robinson-Patman Act-Compulsory Uniform Reciprocity, 37 A.B.A. ANTI-Trust L. J. 77, 89 (1968). In deciding who "competes," judicial analysis goes beyond the mere functional label of a supplier's customer to foeus upon the actuality of competition for the same buyer. Thus, department and variety stores may be customers "competing" with small fabrie stores handling the same product merely as an accommodation to their public. See FTC v. Simplicity Pattern Co., 360 U.S. 55, 62 (1959). Similarly, grocery wholesalers have been considered to be "competing" with specialized institutional contract wagon distributors because both sold to the same type of buyercommercial eating establishments. See General Foods Corp., 52 F.T.C. 798, 825 (1956).

${ }^{140}$ See Fred Meyer, Inc. v. FTC, 359 F.2d 351, 354 (9th Cir. 1966), rev'd on other grounds, 390 U.S. 341 (1968). But see notes 156-61 infra and accompanying text.

141390 U.S. 341 (1968). 
avoid section 2(d) liability, make proportionally equal assistance available to those retailers who compete with the subsidized retailers but indirectly purchase the supplier's products through wholesalers. ${ }^{142}$ The Commission had charged Fred Meyer, a large retail chain, with inducing its suppliers to violate section 2(d) by granting discriminatory promotional payments. ${ }^{1+3}$ The respondent contended that its suppliers had not violated the section because the "disfavored" customers were wholesalers and, thus, did not perform the same functional role as did the respondent. ${ }^{1+4}$ Concomitantly, Fred Meyer argued that those retailers with whom it was "competing" were not entitled to promotional assistance since they, unlike Fred Meyer, purchased from intervening wholesalers rather than directly from the supplier. ${ }^{145}$ Nevertheless, the FTC issued a cease-and-desist order forbidding the respondent from obtaining any promotional aid that was unavailable to any "customers who resell to purchasers who compete with the respondents in the resale of such supplier's products." $1+6$ However, the Court of Appeals for the Ninth Circuit accepted the respondent's "functional roll" defense and reversed the Commission's ruling that a supplier has a duty, under section 2(d), to make promotional aid available to all customers, regardless of their divergent functional positions. ${ }^{147}$

While superficially concurring with the Ninth Circuit's ruling that section 2(d) imposes upon the supplier a duty to offer proportionally equal promotional aid only to customers competing at the same

${ }^{142}$ The Supreme Court ruled "that, when a supplier gives allowances to a direct-buying retailer, he must also make them available on comparable terms to those who buy his products through wholesalers and compete with the direct buyer in resales." Id. at 358.

${ }^{143}$ The Commission alleged that Fred Meyer caused its suppliers to violate $\S 2$ (d) by requesting them to pay a fee totaling $\$ 25,000$ per year for advertisement of the suppliers' products in a coupon-book distributed by Meyer. 63 F.T.C. (1963).

${ }^{144} 63$ F.T.C. at . Compare note 139 supra and accompanying text.

i4s 63 F.T.C. at . See note 149 infra.

${ }^{146} 63$ F.T.C. at . Dissenting, Commissioner Elman argued that the promotional allowances should be made available to retailers who competed with Fred Meyer rather than to wholesalers reselling to these competing retailers. Id. at . This argument was accepted by the Supreme Court. See 390 U.S. at 352.

${ }^{147}$ See Fred Meyer, Inc. v. FTC, 359 F.2d 351 (9th Cir. 1966), in which the Court stated: "[t]he Commission concedes that, to sustain the position taken by it in its opinion, we would have to 'reconsider' our decision in Tri-Valley Packing Ass'n [v. FTC, 329 F.2d 694, 710 (9th Cir. 1964)] . . . where we held, on facts essentially identical with those produced here, that '[n]o section 2(d) violation was shown as to the wholesale operation . . . because that operation was not in functional competition with Meyer . . . " Id. at 362-63. However, the Court decided to "adhere to the result reached [in Tri-Valley]." Id. at 363. 
functional level, ${ }^{148}$ the Supreme Court rejected the lower court's decision that only those having direct dealings with the suppliers were encompassed by the term "customers." 149 Rather, the Court concluded that retailers purchasing the supplier's goods from wholesalers were also "customers" of the suppliers and, since they competed at the same functional level as Fred Meyer, were entitled to proportionately equal promotional treatment. ${ }^{150}$ Noting that the legislative history of the section is inconclusive on the point, ${ }^{151}$ the Court reasoned that expansion of the scope of section 2(d) based upon a broader interpretation of the statutory language ${ }^{152}$ is necessary in order to ensure the protection of small retailers from discriminatory benefits induced by, and granted to, large retail chains for which the section was enacted. ${ }^{153}$ If the Circuit Court's narrow interpretation of "customers" were adopted, suppliers would be allowed to grant selective promotional aid to large retailers who perform their own wholesaling function while denying similar aid to competing small retailers whose only access to suppliers is through wholesalers. ${ }^{154}$ To

\footnotetext{
${ }^{138}$ The Court noted that " $\$ 2$ (d) reaches only discrimination between customers competing for resales at the same functional level and, therefore, does not mandate proportional equality between . . . [a retailer] and . . . wholesalers." 390 U.S. at 349. See notes 138-39 supra and accompanying text.

" 390 U.S. at 354. Before Borden, a buyer was considered a "customer" under the Act only if he either purchased directly from the supplier or if he had had such direct dealings with the supplier, while purchasing from an intermediate distributor, to indicate that he was an "indireet customer" of the supplier and, thus, entitled to proportionally equal treatment. See, e.g., TriValley Packing Ass'n v. FTC, 329 F.2d 694, 709-10 (9th Cir. 1964); American News Co. v. FTC, 300 F.2d 104, 109 (2d Cir. ), cert. denied, 371 U.S. 824 (1962); K.S. Corp. v. Chemstrand Corp., 198 F. Supp. 310, 3i2-13 (S.D.N.Y. 1961); Ballantine Books, Inc., 61 F.T.C. 23, 26 (1962); Feature Publications, Inc., 61 F.T.C. 19, 22 (1962); Mercury Press, Inc., 61 F.T.C. 15, 18 (1962); Gernsback Publications, Inc., 61 F.T.C. 12, 15 (1962); Johnson Publishing Co., 61 F.T.C. 8, 11 (1962); Kay Windsor Frocks, Inc., 51 F.T.C. 89, $95-96$ (1954); Luxor Inc., 31 F.T.C. 658, 662-63 (1940). See generally Rowe at 398-99; Fisher, note 94 supra, at 476-77; Comment, 29 U. CHI. L. Rev. at 176-80. However, the Supreme Court negated the direct contact requirement, stating "the requirement of direct dealing between supplier and disfavored competitors . . . rests on too narrow a rcading of the statute." 390 U.S. at 354.

iso See note 142 supra.

is " $[N]$ either the Committee Report nor other parts of the legislativc history . . . defines 'customer' to include retailers who purchase through wholesalers and compete with direct buyers in resales." 390 U.S. at 352.

is2 See note 149 supra.

iss This was described as "Congress' clearly stated intent." 390 U.S. at 352.

ist The Court concluded that "a narrower reading of $\S 2$ (d) would lead to the following anomolous result. . . . [D]irect-buying retailers like Meyer, who resell large quantities of their suppliers' products and thercfore find it feasible to undertake the traditional wholesaling functions for themselves, would be protected by the provision from the granting of
} 
avoid this anomalous result, the Court decided that section 2(d) had been violated by Fred Meyer's suppliers' failure to offer promotional assistance to the retailers purchasing through wholesalers. ${ }^{155}$

While the Court did not directly challenge the functional level defense, ${ }^{156}$ the practical value of the defense seems effectively debilitated by the imposition of a duty upon a supplier to offer promotional assistance to subsequent, indirect purchasers of his goods who are at the same functional level as direct customers receiving subsidization. ${ }^{157}$ While prior to Fred Meyer, Inc., a respondent-supplier could permanently avoid section 2(d) or 2(e) liability for promotional discrimination between customers by proof that the vendees performed different functional roles, ${ }^{158}$ the functional level defense now may be only of temporary effectiveness. Thus, the decision indicates that a supplier is apparently free of the "availability" requirements of section $2(\mathrm{~d})$ or $2(\mathrm{e})$ only so long as his products are not, after the initial direct sale to different functional levels, resold to buyers "competing at the same level as any of the subsidized supplier's vendees."159 However, the decision fails to delineate the degree of knowledge which must be possessed by the supplier before the enhanced duty under section $2(\mathrm{~d})$ is imposed. It remains unclear whether the supplier must have actual knowledge of the later transfer, seemingly the factual situation in Fred Meyer, Inc. ${ }^{160}$ or merely must have reason to know of the transfer, or will be charged with knowledge of the transfer in all cases. Arguably, if the

discriminatory promotional allowances to their direct-buying competitors. On the other hand, small retailers whose only access to suppliers is through independent wholesalers would not be entitled to this protection." 390 U.S. at 352 . This result was seen to "be diametrically opposed . . ." to Congress' purpose in enacting $\$ 2$ (d). Id.

iss However, the Court attempted to limit the precedential effect of Fred Meyer, Inc., stating that "it would be both inappropriate and unwise to attempt to formulate an all-embracing rule applying the elusive language of the section to every system of distribution a supplier might devise , . ." 390 U.S. at 357. Rather, the Court indicated that the decision was limited to "the concrete facts here presented. ..."Id.

${ }^{136}$ See note 148 supra and accompanying text.

157 However, this "new" duty is presumably also limited by the passage of time, see notes 125 31 supra and accompanying text, the presence of geographic barriers between direct and indirect purchasers, see notes 132-37 supra and accompanying text, and the requirements of like grade and quality. See notes 111-24 supra and accompanying text.

1s9 See note 138 supra.

159 See notes 142 \& 149 supra and accompanying text.

${ }^{160}$ The Court of Appeals indicated that the suppliers in Fred Meyer not only had knowledge that they were selling to wholesalers who bought for the purpose of resale but also that the supplier knew to whom these wholesalers resold. See 359 F.2d at 365-66. 
supplier's duty operates upon either of the latter two standards, the administrative cost and difficulties inherent in a continuing surveillance regarding ownership of his products will significantly discourage a supplier's propensity to make any offers of promotional assistance where there is a mere possibility of distributive resale. ${ }^{161}$

On the other hand, the substantive holding of Fred Meyer. Inc., may be less significant to the respondent preparing a defense to sections 2(d) and 2(e) allegations than is the Court's method of analysis in reaching the holding. While ostensibly basing their ruling upon an extraordinarily broad interpretation of "customers," "162 the Court actually seems to have decided the case by engaging in an economic analysis of the ramifications of the various alternative holdings in light of the primary purpose of section 2 (d) to improve the competitive position of small retailers. ${ }^{163}$ Moreover, once having

\footnotetext{
${ }^{161}$ The Court suggested that a supplier might make the promotional offers required under the decision by "utilizing his wholesalers to distribute payments or administer a promotional program, so long as the supplier takes responsibility ... for seeing that the allowances are made available to all who compete in the resale of his produet." 390 U.S. at 358 . Sec note 101 supra and accompanying text. However, the extreme difficulties of such a system were outlined in the oral arguments before the Court: "Faced with a case where the supplier is forced to pay an allowance to the wholesaler. . . it would be impossible to do all the things that the FTC would require [the wholesaler] to do. The wholesaler would have to find out which retailers compete with the direct-buying retailer and how to proportionalize it, and then he has to determine whether the plan is suitable for the small retailer to use .... The wholesaler would have to colleet the money and pass it on, sec that it's used and if not used, see that it is remitted."
}

36 U.S.L.W. at 3198.

The compensation that wholesalers would require to perform this "impossible" task might so increase the cost of the promotion as to make it prohibitive. Similarly, if the supplier attempts to perform those administrative tasks outlined above and the additional task of establishing a liason with the intermediate distributor to trace the supplier's goods from that distributor to their ultimate buyer, the cost in time and money may be much greater than the expected return from the promotion granted.

${ }^{162}$ See note 149 supra and accompanying text.

${ }^{163}$ Sec note 153 supra and accompanying text. The Court's analysis focused upon the "central purpose of $\$ 2(\mathrm{~d})$ and the economic realities with which its framers were concerned." 390 U.S. at 349. This "central purpose," as defined by the Court, was "to improve the competitive position of small retailers by eliminating [discriminatory promotional allowances]." Id. at 352. The "economic realities" with which the Court was concerned seem to havc been the competitive effects upon these "small retailers" of the promotional aid granted Fred Meyer. The Court stated "it is clear that the direct impact of Meyer's receiving discriminatory promotional allowances is felt by the disfavored retailers with whom Mcyer competes in resales." Id. at 357. Indeed, the basis of the Court's extraordinary interpretation of "customers," sec notc 149 supra and accompanying text, is that "[w]hether suppliers deal directly with the disfavored competitors or not, they can, and here did, afford a direct buyer the kind of competitive advantage which $\$ 2$ (d) was intended to climinate." 390 U.S. at 354. 
viewed the economic realities, the Court limited its decision to the factual circumstances presented, explicitly refusing to set forth a general rule. ${ }^{164}$ This ad hoc approach represents a significant departure from the courts' and Commission's general refusal to consider the economic effects of an alleged violation or of their decision. ${ }^{165}$ Rather, analysis has been primarily confined to a literal interpretation of the rather poorly drafted statutory language. ${ }^{166}$ Thus, perhaps the most important ultimate aspect of Fred Meyer, Inc., may be to influence affirmatively application of an economically realistic analysis resulting in invocation of sections 2(d) and 2(e) only when the facts presented indicate that a competitive injury to the small retailer is likely. ${ }^{167}$

The statutory prerequisite to application of section 2(d) or 2 (e) that there be "competing" customers-interpreted as customers purchasing at a reasonably simultaneous time, reselling goods of like grade and quality, at the same functional level within the same geographic market-is a necessary and reasonable qualification of the statutory proscriptions upon indirect price rebates. Since the purpose of these prohibitions is to protect the small retailer rather than to preclude all promotional subsidization, the statute should logically operate to accomplish its narrow end without restraining commerical transactions which do not affect the small retailer's competitive position. ${ }^{168}$ Consequently, the respondent's ability to defend against a section 2(d) or 2(e) allegation by proving the absence of any of the above definitional elements of a "competing customer," and thereby establishing that his subsidized customer does not, in fact, compete with any other customer who

\footnotetext{
${ }^{164}$ See note 155 supra:

16s See note 92 supra.

${ }^{165}$ See, e.g., FTC v. Simplicity Pattern Co., 360 U.S. 55 (1959); R.H. Macy \& Co. v. FTC, 326 F.2d 445 (2d Cir. 1964); Vanity Fair Paper Mill, 1nc. v. FTC, 311 F.2d 480 (2d Cir. 1962); Alexander Miner Sales Corp., 61 F.T.C. 1317 (1962); Johnson Publishing Co., 61 F.T.C. 8 (1962); Henry Rosenfeld, Inc., 52 F.T.C. 1535 (1956).

${ }^{167}$ See note 168 infra and accompanying text.

${ }^{168}$ While recognizing the Act's purpose in "protect [ing] . . . certain elements in the business community [the small individual competitor] against the effective price and service competition of others," Oppenheim, Federal Antitrust Legislation: Guideposts to a Revised National Antitrust Policy, 50 Mich. L. Rev. 1139, 1200 (1952), a leading commentator has suggested that the Robinson-Patman Act be "applicable to the prohibition of price and service discriminations only where the effect may be to substantially lessen competition or tend to create a monopoly at any level of competition . . . " Id. at 1202. Thus, it was suggested that actionable "[d]iscrimination arising from failure of the seller to offer comparable payments or
} 
would be adversely affected, is an effective means of attaining the proper discriminatory application of the statute. Moreover, the undifferentiated enforcement which might otherwise ensue would seem inconsistent with the general regulatory policy of interfering with free business enterprise only when deleterious effects upon competition are either probable or certain. ${ }^{169}$ Arguably, equivalent justifications could be advanced for a sub silentio extension of the same stringent competitive injury defense to the brokerage clause. There seems to be no compelling economic rationale in support of more severe treatment of section 2 (c) violators since dummy brokerage and discriminatory promotional assistance are equally invidious in their ultimate effect, a competitively advantageous reduction of the selected customer's costs. However, section 2(c)'s textual silence regarding the "competing" requirement ${ }^{170}$ and the resulting general refusal of the FTC and the courts to consider the possible competitive effects of selective brokerage payments ${ }^{171}$ may be explained by the surreptitious element present in 2(c) violations, the

services or facilities to all of his customers on equal terms would depend upon whether the effect may be substantially to lessen competition." Id. at 1207 . More recently, Commissioner Elman bas concluded tbat "[t]he utility of a per se approach [of section 2(d) and 2(e)] remains highly doubtful, at the very least." See Elman, The Robinson-Patman Act and Anti-Trust Policy: A Time for Reappraisal, 42 WASH. L. REv. 1, 27 (1966). See also ATt'y GEN. ReP. 189-90.

${ }^{169}$ See, e.g., Att'y Gen. Rep. 191-92; C. Edwards, The Price Discrimination Law 627-57 (1959); Elman, note 168 supra, at 2-4; Oppenheim, note 168 supra, at 1198-1210.

The general antitrust policy embodied in the Sherman Act, 15 U.S.C. $\$ \S 1-7$ (1964), $\S 5$ of the Federal Trade Commission Act, 15 U.S.C. $\$ 45$ (1964), and sections 3 and 7 of the Clayton Act, 15 U.S.C. $\$ \S 14$ \& 18 (1964), has been described as that of "hard competition," allowing market pressures, including relative bargaining power, to operate freely unless they substantialiy injure competition or tend to create monopoly. See Oppenheim, note 168 supra, at 1198-1203. However, the Robinson-Patman Act's policy has been seen as "soft competition," restraining activities that injure the position of a selected member of the economy, the individual competitor. Id. at 1201. In order to make sections 2(d) and 2(e) more consistent with this poliey, tbe ablution of these seetions has been advocated. See note 84 supra.

${ }^{170}$ See note 4 supra.

${ }^{171}$ See, e.g., Robinson v. Stanley Home Prods., lnc., 272 F.2d 601, 604 (1st Cir. 1959); Southgate Brokcrage Co. v. FTC, 150 F.2d 607, 609-10 (4th Cir.), cert. denied, 326 U.S. 774 (1945). It has been contended that " $\$ 2(c)$ is the only substantive section which does not deal with the discriminatory treatment of two or more competitors. Since no question of discrimination exists, and since the offense does not even require the presence of competitors, competitive injury can have no relevance in a $\$ 2$ (c) case." Note, 68 YALE L.J. 808, 824 n.87 (1959). But see Rill, Brokerage Under the Robinson-Patman Act: Toward a New Certainty, 41 Notre DaMe LAw. 337, 348 (1966). On the other hand, it has been suggested that like grade and quality, geographic proximity, and functional level should be considered in brokerage violations to determine whether the disadvantaged buyers are in competition with the favored buyer. Id. 
sham brokerage practices engaged in to deceive others as to the actual price paid for the suppliers' goods, which is not usually evident in sections 2(d), 2(e), or 2(a) violations. ${ }^{172}$

Although failing to effectuate the section 2(d) and 2(e) defenses by proof that the promotional aids granted were not discriminatory because accorded on proportionally equal terms or that actual competitive injury was impossible, a respondent may nevertheless avoid section 2(e) charges by proving that his promotional grants were a good faith effort to meet competition, the defense provided by section 2(b) of the Robinson-Patman Act. ${ }^{173}$ However, the burdensome evidentiary requirements conditioning the utilization of this defense in section 2(a) litigation have been extended to section 2(e) cases, causing operation of the defense to depend upon possession of extensive information regarding the competitor's activities. ${ }^{174}$ Thus, because the gravamen of the defense is that a supplier's actions were merely responsive to promotional offers of his competitors, the respondent must establish that he had knowledge of his competitor's offer of promotional benefits. ${ }^{175}$ Although not required, a supplier

${ }^{172}$ Unlike a section 2(a), 2(d), or 2(e) violation, "[t]he gist of the violation under section 2(c) is not that discriminatory prices have been charged, but that the parties have engaged in a practicc designed to deceive others as to the price charged and paid, whether or not discriminatory." FTC v. Washington Fish \& Oyster Co., 271 F.2d 39, 44 (9th Cir. 1959). But see notes 27-33 supra and accompanying text. Since this invidious intent element of a section 2(c) violation has been cited as the reason that a "meeting competition" defense is not available to those charged under the brokerage clause, Blackford, $A$ Survey and Commentary on the Good Faith Meeting of Competition Defense in the Robinson-Patman Act, 18 W. RES. L. REv. 753, 757-58 (1967), it may also be the cause of the unwillingness of the courts to consider the competitive impact of brokerage violations.

${ }^{173}$ Seetion 2(b) provides that "a seller [may rebut al prima facie case . . . by showing that his lower price or the furnishing of services or facilities to any"purchaser or purchasers was made in good faith to meet an equally low pricc of a competitor, or the services or facilities furnished by a competitor." Robinson-Patman Act § 2(b), 15 U.S.C. § 13(b) (1964). The Supreme Court has recognized the section 2(b) defense as a complete defense to Robinson-Patman charges. FTC v. Standard Oil Co., 355 U.S. 396 (1958). See generally Rowe 207-64, 416-20; Austern, Presumption and Persipience About Competitive Effect Under Section 2 of the Clayton Act, 81 HARv. L. REv. 773, 810-17 (1968); Blackford, note 172 supra; Elman, note 168 supra, at 16-21; Kintner, Merchandising Allowances and Services: Sections 2(d) and 2(e) of the Robinson-Patman $A c t, 41$ Notre Dame LAw. 364, 369-70 (1966).

${ }^{174}$ Blackford has warned that "[i]f the Commission adheres to its present interpretation as to the type and sufficiency of evidence required of a seller to sustain his burden of proof, then for all practical purposes the good faith meeting of competition defense is not a viable mcans of justifying a discriminatory practice in an FTC proceeding." Blackford, note 172 supra, at 771 . The FTC has stated that "this is a very technical defense subject to important limitations." FTC Guides § 240.14.

${ }^{175}$ According to the Supreme Court "the statute at least requires the seller, who has knowingly 
might bolster the argument that his actions were strictly defensive by delaying his retaliatory action until he has suffered actual competitive injury. ${ }^{176}$ Moreover, it is generally required that the promotional assistance provided not exceed that offered by the supplier's competitors. ${ }^{177}$ Therefore, thc respondent must know the specifics of his competitor's schemes of assistance and be able to show that the amount of subsidy or the cost of services which he provides is not greater than that granted by his competitors. Finally, the section 2(b) defense operates to justify only reaction to legal competition. ${ }^{178} 1 \mathrm{f}$ it is determined that a reasonably prudent supplier should have known that the promotional offers made by his competitors were illegal, the Commission will refuse to condone discriminatory aid as necessary to meet competition. ${ }^{179}$ However, this "legality" requirement has been

discriminated in price, to show the existence of facts which would lead a reasonable and prudent person to believe that the granting of a lower price would in fact meet the equally low price of a competitor." FTC v. A.E. Staley Mfg. Co., 324 U.S. 746, 759-60 (1945); accord, Continental Baking Co., No. 7630 (F.T.C., December 31, 1963). However, the respondent is not required to demonstrate knowledge of the specific terms of a competitor's offer. See Forstcr Mfg. Co. v. FTC, 335 F.2d 47, 55-56 (1st Cir. 1964), cert. denied, 380 U.S. 906 (1965); cf. Callaway Mills v. FTC, 362 F.2d 435, 441-42 (5th Cir. 1966).

${ }^{176}$ Cf. Callaway Mills Co. v. FTC, 362 F.2d 435 (5th Cir. 1966) (respondent waited five years before relinquishing to pressure and meeting competitors' discounts). See also Continental Baking Co., No. 7630 (F.T.C., December 31, 1963).

${ }^{177}$ A section 2(b) defense has been disallowed where the Courts have determined that the scller has attempted to gain new customers rather than merely retain his present customers by offering lower prices than those of his competitors. See, e.g., Standard Oil Co. v. FTC, 340 U.S. 23I, 24142, 249 (1951); Standard Motors Prods., Inc. v. FTC, 265 F.2d 674, 677 (2d Cir.), cert. denied, 361 U.S. 826 (1959); Exquisite Form Brassiere, Inc., 57 F.T.C. 1036, 1045-46 (1960), modified, 301 F.2d 499 (D.C. Cir. 1961), cert. denied, 369 U.S. 888 (1962). Contra, Sunshine Biscuit, Inc. v. FTC, 306 F.2d 48 (7th Cir. 1962). Presumably, this same requirement of "meeting not beating" a competitor's offer applies cqually in defense to section 2(d) or 2(e).

This limitation upon the section 2(b) defense has been criticized as contrary to the fundamental goal of other antitrust legislation, Blackford, note 172 supra, and "inconsistent with the Sherman Act which makes it a per se offense to allocate customers or to attempt to monopolize your own customers." Austern, note 173 supra at 816 . Thus, it has been suggested that aggressive pricing practices, presumably including promotional aid, be allowed in meeting competition unless the seller had both the intent and the economic power to destroy rather than merely injure his competition. Blackford, note 172 supra, at 778.

17 The Supreme Court has stated that the competitor's price that could be met would be a "lawful lower price." Standard Oil Co. v. FTC, 340 U.S. 231, 238, 242, 252 (1951). See generally Rowe 220-30.

${ }^{179}$ See, e.g., Tri-Valley Packing Ass'n, 60 F.T.C. 1134, 1172 (1962), rev'd on other grounds, 329 F.2d 694 (9th Cir. 1964); E. Edelman \& Co., 5 I F.T.C. 978 (1955), affd, 239 F.2d 152 (7th Cir. 1956), cert. denied, 355 U.S. 941 (1958); Standard Motors Prods., Inc., 54 F.T.C. 814 (1957), affd, 265 F.2d 674 (2d Cir.), cert. denied, 361 U.S. 826 (1959). 
criticized as unreasonable since it requires a supplier to judge the propriety of his own acts upon speculation concerning the legality of his competitors' operations based upon facts to which access is extremely difficult. ${ }^{180}$ Consequently, several courts have promulgated a more lenient "legality" requirement than that favored by the FTC under which the section 2(b) "meeting competition" defense is rejected only if the respondent has actual knowledge or must have known that his competitor's actions are illegal. ${ }^{181}$ Moreover, it has been suggested that, because of the onerous burden of speculation, the legality of a competitor's offer should not be considered unless the Commission finds a reciprocal collusive agreement between the suppliers. ${ }^{182}$

Although the scope of the "meeting competition" defense has traditionally been limited to sections 2 (a) and $2(e),{ }^{183}$ several recent decisions have held the defense available to those charged under

However, the Attorney General's Report, fully cited note 17 supra, did not "interpret the Supreme Court's [Standard Oil] decision as establishing such lawfulness as an absolute condition in every section 2(b) ... . defense [but] [r]ather . . . [as merely] exclud[ing] a price established pursuant to a conspiracy or an illegal single basing-point system, or otherwise unrelated to potential differences in the rival seller's costs." ATT'Y GEN. REP. at 182. See notes 181-82 infra and accompanying text.

${ }^{180}$ In the competitive market situation, the seller faced with a competitor's promotional offer is required by the reasonable-man rule to speculate as to whether his competitor has met the requirements of proportional equal treatment, see notes 97-1 10 supra and accompanying text, of all competing customers. See notes 111-72 supra and accompanying text. This speculation has been described as "especially onerous for the private litigant who is not armed with the investigatory powers of the FTC . . ." and as "a costly proposition." See Blackford, note 172 supra, at 763. Thus, it seems clear that "[a] businessman who operates in the haste and pressures of the market cannot always prophesy whether the competitor's price [or promotional offer] which he must meet may later be held unlawful; nor is the overall antitrust policy furthered by information exchangc programs to spread such knowledge among competitors." ATT'Y GEN. REP. 182. See also Austern, note 173 supra, at 814-16.

1" See Standard Oil Co. v. Brown, 238 F.2d 54 (5th Cir. 1956). Moreover, courts have shown greater leniency as to the legality requirement in distinguishing between an illegal system and an individual offer. Although mecting competition is not available in meeting a system, see, e.g., FTC v. A.E. Staley Mfg. Co., 324 U.S. 746, 753 (1945); Corn Prods. Ref. Co. v. FTC, 324 U.S. 726, 735 (1945), there are indications that some courts will allow a supplier to "meet" individual illegal competitive offers. See Balian Ice Cream Co. v. Arden Farms Co., 231 F.2d 356 (9th Cir. 1955), cert. denied, 350 U.S. 991 (1956); Dean Milk Co. v. American Processing \& Sales Co., 1950-1951 Trade Cas. If 64,301 (N.D. Ill. 1951).

12 See Blackford, note 172 supra, at 778.

${ }^{133}$ In Henry Rosenfeld, Inc., 52 F.T.C. 1535 (I956), the Commission first ruled that "meeting competition" was not a defense to section 2(d). Id. at I552. Finding the legislative history of the Act inconclusive, id. at 155I, the Commission narrowly interpreted the text of section 2(b), see note 173 supra, ruling that the defense was unavailable to a section 2(d) defendant because neither "payments" nor "allowances" were mentioned as justifiable in section 2(b). Id, at 1552; accord, Admiral Corp., 55 F.T.C. 2078 (1959); J.H. Filbert, Inc., 54 F.T.C. 359, 364 
section 2(d). ${ }^{184}$ Restrietion of the section 2(b) defense to sections 2(a) and 2(e) was based upon a strict literal interpretation of seetion 2(b)'s description of the actions that might be justified as "meeting competition." The word "furnishing" was interpreted to include only the direct grants of promotional services or facilities described in section 2(e) and not payments for promotion under section 2(d). ${ }^{185}$ However, the legislative history of the Robinson-Patman Act indicates that the bill contained only section 2 (d) at the time section 2(b) was adopted. ${ }^{186}$ Thus, several courts have inferred that sections 2(d) and 2(e) are companionate and that section 2(b) necessarily is available to both..$^{187}$ Arguably, extension of the section 2(b) defense to section $2(d)$ is correct since little reason appears for differential treatment in light of the fact that the sections are violated by substantively equivalent activities and that the eustomer cost mitigation effect is identical under section $2(\mathrm{~d})$ or $2(\mathrm{e}){ }^{188}$ Furthermore, application of section 2(b) to both sections 2(d) and 2(e) seems economically justified since the unavailability of a "meeting competition" defense may result in operation of the promotional provisions to favor unduly the large, vertically integrated company over smaller non-integrated suppliers and customers. For example, where commer-

(1957); cf. Great Atl. \& Pac. Tea Co. v. FTC, 106 F.2d 667, 677 (3d Cir. 1939) (dictum), cert. denied, 308 U.S. 625 (1940).

is Shulton, Inc. v. FTC, 305 F.2d 36 (7th Cir. 1962); Exquisite Form Brassiere, Inc. v. FTC, 301 F.2d 499 (D.C. Cir. 1961). See generally Note, 48 VA. L. Rev. 574 (1962); 30 Geo. WaSH. L. Rev. 769 (I962); I3 SyRACUSE L. Rev. 473 (1962).

iss See authority cited in note 183 supra.

${ }^{125}$ The District of Columbia Circuit noted that "as the bill passed the Senate . . . it included (1) our present Subsection (d) ...; (2) a separate subsection making unlawful any discrimination in discounts, rebates, allowances, or advertising service charges; and (3) the meetcompetition defense .... [T]he bill ... contained no Subsection (e) or any equivalent thereof." $301 \mathrm{~F} .2 \mathrm{~d}$ at 504.

ist "Thus there can be no doubt whatsoever that, so far as the Senate was concerned, the proviso in Subseetion (b) applied to discriminations in compensation or allowances made to customers for services or facilities furnished by them, as now provided in Subseetion (d); there was nothing else in the bill for this language to apply to [sic]." Id.; accord, Shulton, Inc. v. FTC, 305 F.2d 36, 38 (7th Cir. 1962); Exquisite Form Brassiere, Inc. v. FTC, 301 F.2d 499, 502 (D.C. Cir. 1961), cert. denied, 369 U.S. 888 (1962) (where the previous strict interpretation of section 2(b) was described as "unrealistic").

ist "In the typical situation concerning advertising services, it does not matter which party 'furnished' the services since the expense ultimately will fall on the seller even though the customer enjoys some of the resulting benefits. Thus, the economic effeet of the transaction is identical whether the seller pays for the services directly or indirectly. . . . [1]t is submitted that competition is not fostered by preferring one type of discrimination over another closely related form of economic favoritism." Note, 48 VA. L. REv. 574, 595 (1962). 
cially independent suppliers and customers conjunctively compete with a vertically integrated enterprise, the integrated company may gain competitive advantage by using promotional programs that the individual customers cannot afford. Since the independent supplier would not be permitted, absent the availability of a "meeting competition" defense, to provide promotional assistance to the particular customers disadvantaged without simultaneously extending identical aid to all customers throughout the market area, an endeavor likely requiring expenditures exceeding the benefits returned to the supplier, the integrated company's scheme would remain unchallenged. Consequently, the individual customer might lose sales volume to the integrated company and perhaps be driven from business by an effective promotional campaign. ${ }^{189}$ Thus, in order effectively to attain the goal of protecting the small customer espoused by sections 2(d) and 2(e), the "meeting competition" defense should be available to suppliers granting assistance within the terms of either section. ${ }^{190}$

A trend, similar to that apparent in recent section 2(c) decisions, toward extending section 2(a) defenses to sections 2(d) and 2(e) is developing. ${ }^{191}$ The elements of a violation of section $2(d)$ or $2(e)$ and, conversely, the gist of their defenses, are similar to those of section 2(a). Under each provision, discrimination and the possibility of consequent competitive injury are required to establish a violation. However, unlike section 2(a), these elements are presumed under 2(d) and 2(e). ${ }^{192}$ Thus, as a matter of defense, the burden is upon the respondent to rebut these presumptions by establishing that there were no "competing" customers or that his promotional benefits were accorded in equal proportion. The practical difficulties of this rebuttal seems to fulfill the Congressional goal of encouraging parties to restrict their discriminatory activities to section 2(a) price differentials ${ }^{193}$ where the Commission bears the burden of establishing

\footnotetext{
${ }^{189}$ Cf. FTC v. Sun Oil Co., 371 U.S. 505 (1963).

${ }^{190}$ It seems that the Commission has finally recognized the validity and necessity of the extension of the section 2(b) defense to section 2(d) for it now advises that "[a] seller charged with discrimination in violation of section $2(d)$ or section $2(e)$ may defend his actions by showing that the payments were made or the services were furnished in good faith to meet equally high payments or equivalent services paid or furnished by a competitor." FTC Guides $\$ 240.14$ (emphasis added).

"9' See notes 81-88 supra and accompanying text.

${ }^{192}$ See Simplicity Pattern Co. v. FTC, 360 U.S. 55 (1959); note I6 supra.

${ }^{193}$ See note 18 supra and accompanying text.
} 
the elements of injury and discrimination. ${ }^{194}$ At the same time, the respondent is at least afforded an opportunity to avoid the sections by showing that his actions were innocent. Further, the extension of an effective "meeting competition" defense to both sections 2(d) and 2(e) represents an astute recognition of the economic necessity of retaliation in a competitive economy. ${ }^{195}$

\section{CONCLUSION}

There is reason for some optimism upon the part of a respondent charged under section 2(c), 2(d), or 2(e) since the Federal Trade Commission and some courts are apparently becoming more economically realistic in allowing justifications for prima facie violations of these sections. However, it would be misleading to suggest that the utilization of the described defenses will certainly be successful. The fluctuating composition of the Commission will continue to affect, if not determine, its acceptance of a particular defense. Moreover, the courts continue to differ among themselves and with the Federal Trade Commission as to the specific elements required for, and in their general sympathy toward, the economically justified defenses. Thus, the future effectiveness of sections 2(c), 2(d), and 2 (e) defenses remains impervious to valid generalization.

\footnotetext{
194 See generally Black ford, $A$ Survey of Section 2(a) of the Robinson-Patman Act, 41 NoTRE DAME LAW. 285, 295-99 (1966).

${ }^{195}$ Indicating the necessity of spontaneity in this retaliation, Austern, Isn't 30 Years Enough, 30 A.B.A. Anti-Trust L.J. 1 (1966) warns: "If the meeting competition defense is to have any practical meaning, it must be given a flexible interpretation enabling sellers to act promptly in response to the exigencies of competition. Sensitivity to the realities of everyday eommercial life, not rigid standards imposing unrealistic and impossible duties of inquiry and prediction on the businessmen, is essential if the defense is to have any substance. Pragmatism, not strict loglc must be the keynote of interpretation." Id. at 17 (emphasis added).
} 